\title{
Unravelling Evidence for Global Climate Change in Mississippian Carbonate Strata from the Derbyshire and North Wales Platforms, UK
}

DOI:

10.1144/jgs2020-106

\section{Document Version \\ Accepted author manuscript}

Link to publication record in Manchester Research Explorer

Citation for published version (APA):

Manifold, L., Del Strother, P., Gold, D. P., Burgess, P., \& Hollis, C. (2021). Unravelling Evidence for Global Climate Change in Mississippian Carbonate Strata from the Derbyshire and North Wales Platforms, UK. Journal of the Geological Society, jgs2020-106. https://doi.org/10.1144/jgs2020-106

Published in:

Journal of the Geological Society

\section{Citing this paper}

Please note that where the full-text provided on Manchester Research Explorer is the Author Accepted Manuscript or Proof version this may differ from the final Published version. If citing, it is advised that you check and use the publisher's definitive version.

\section{General rights}

Copyright and moral rights for the publications made accessible in the Research Explorer are retained by the authors and/or other copyright owners and it is a condition of accessing publications that users recognise and abide by the legal requirements associated with these rights.

\section{Takedown policy}

If you believe that this document breaches copyright please refer to the University of Manchester's Takedown Procedures [http://man.ac.uk/04Y6Bo] or contact uml.scholarlycommunications@manchester.ac.uk providing relevant details, so we can investigate your claim.

\section{OPEN ACCESS}




\title{
Journal of the Geological Society
}

\section{Unravelling Evidence for Global Climate Change in Mississippian Carbonate Strata from the Derbyshire and North Wales Platforms, UK}

\author{
L. Manifold, P. del Strother, D.P. Gold, P. Burgess \& C. Hollis
}

DOI: https://doi.org/10.1144/jgs2020-106

To access the most recent version of this article, please click the DOI URL in the line above. When citing this article please include the above DOI.

Received 5 June 2020

Revised 18 February 2021

Accepted 19 February 2021

(C) 2021 The Author(s). Published by The Geological Society of London. All rights reserved. For permissions: http://www.geolsoc.org.uk/permissions. Publishing disclaimer:

www.geolsoc.org.uk/pub_ethics

\section{Manuscript version: Accepted Manuscript}

This is a PDF of an unedited manuscript that has been accepted for publication. The manuscript will undergo copyediting, typesetting and correction before it is published in its final form. Please note that during the production process errors may be discovered which could affect the content, and all legal disclaimers that apply to the journal pertain.

Although reasonable efforts have been made to obtain all necessary permissions from third parties to include their copyrighted content within this article, their full citation and copyright line may not be present in this Accepted Manuscript version. Before using any content from this article, please refer to the Version of Record once published for full citation and copyright details, as permissions may be required. 


\section{Unravelling Evidence for Global Climate Change in Mississippian Carbonate Strata from the Derbyshire and North Wales Platforms, UK}

Manifold, L.*1, del Strother, P.*, Gold, D.P1., Burgess, P. ${ }^{2}$ Hollis, C.*

Lucy Manifold: Department of Earth and Environmental Sciences, University of Manchester, M13 9PL/CGG

Robertson, Llandudno, LL30 1SA

Peter del Strother: Department of Earth and Environmental Sciences, University of Manchester, M13 9PL

David P. Gold: CGG Robertson, Llandudno, LL30 1SA

Peter Burgess: Department of Earth, Ocean and Ecological Sciences, University of Liverpool, L69 3BX

Cathy Hollis: Department of Earth and Environmental Sciences, University of Manchester, M13 9PL

\section{ABSTRACT}

The Mississippian Derbyshire and North Wales carbonate platforms were formed in similar tectonic settings within the Pennine and East Irish Sea Basin, respectively. The Derbyshire Platform was surrounded by sub-basins to the north, west, and south whilst the North Wales Platform, $130 \mathrm{~km}$ west, had a simpler land-attached geometry. Comparison of these age-equivalent platforms allows the controls on sedimentation, at an important juncture in Earth history, to be evaluated. Both platforms are dominated by moderate-to-high-energy, laterally discontinuous facies, with weak evidence for facies cyclicity, suggesting multiple controls on deposition. Influx of siliciclastic mud on the North Wales Platform led to perturbations in carbonate accumulation; along with abundant palaeosols and coal beds this implies a more humid climate, or shallower water depths compared to the Derbyshire Platform. On both platforms, exposure surfaces can rarely be correlated over $>500$ metres except for a regionally correlative palaeokarstic surface at the Asbian-Brigantian boundary. This exposure event appears to coincide with a significant regional facies change. Given the lack of evidence for ordering and cyclicity within the strata, the Asbian-Brigantian boundary may mark a significant event that could reflect onset of a transitional climate, prior to the second glaciation event in the Late Palaeozoic Ice Age. 


\section{INTRODUCTION}

The Mississippian was an important period of Earth history, when climatic changes were underway as a result of the onset of the Gondwanan glaciation and continental reorganisation associated with the closure of the Rheic Ocean, prior to the Laurentian and Gondwanan collision (Sandberg, 1983; Wright and Vanstone, 2001; Haq and Schutter 2008; Cocks and Torsvik, 2011). Although there was reduced taphonomic diversity in the earliest Carboniferous, following the Frasnian-Fammenian mass extinction, rebound was rapid with the evolution of land plants and insects and a diverse submarine biosphere that dominantly comprised rugose corals, bryozoa, crinoids, brachiopods, and foraminifera (Heckel, 1974; James, 1983; Copper, 1988). The diversification of land plants, increased chemical weathering and mountain building have all been touted as triggers for the onset of the Late Palaeozoic Ice Age (LPIA) (Godderis et al, 2017), but the timing of the formation of ice sheets and the impact of glaciation on sedimentary architecture is still very much debated. There is widespread general acceptance that two periods of ice formation pre-dated the main glaciation in the Pennsylvanian. These ice pulses have been estimated to have occurred during the Tournasian and Viséan (Lakin et al., 2016; Liu et al., 2019), with the timing of the onset of the second period of ice-sheet formation estimated to range from $\sim 335 \mathrm{Ma}$ (mid-Viséan; Wright and Vanstone, 2001; Poty, 2016) to $322 \mathrm{Ma}$ (Serphukhovian; Buggish et al., 2008). Evidence for changes in sedimentation on sub-equatorial Mississippian carbonate platforms as a result of glacioeustacy have focused upon a change from low frequency to high frequency sedimentary cyclicity (Wright and Vanstone, 2000), deep incision of carbonate platforms at unconformities (Smith and Read, 2000) and isotopic perturbations associated with changes in organic carbon burial and denitrification, driven by ocean cooling (e.g. Buggisch et al., 2008; Liu et al., 2019).

Viséan carbonate platforms in northern Europe are well-studied (e.g. van Hulten and Poty, 2008; Somerville, 2008; Poty et al., 2014; Poty, 2016; Herbig, 2016), and the tectono-stratigraphic evolution of the Pennine - Irish Sea Basin and southern Euramerican continent during the Mississippian is also well established (Cocks and Torvisk, 2011; Fraser and Gawthorpe, 2003). This study is focused upon the Derbyshire and North Wales Platforms, which are situated in the northern UK within the Pennine Basin (Figure 1). During the lower Carboniferous, both platforms were located on the northern margin of the Wales-Brabant Massif and the southern margin of the Pennine - Irish Sea Basin, which was an equatorial, intra-cratonic seaway north of the Rheic Ocean. The Derbyshire Platform is a Viséan (lower Carboniferous) platform with a long history of study (e.g. Wolverson Cope 1936, 1938; Shirley and Horsfield 1940; Stevenson and Gaunt, 1971; Aitkenhead et al., 1985; Harwood, 2005). Most publications, however, are local case-studies, and do not describe the depositional architecture of the whole platform. Moreover, much of the literature pre-dates modern sedimentological paradigms, such as sequence stratigraphy. The North Wales Platform, situated $130 \mathrm{~km}$ westwards, is relatively understudied in comparison (Ramsay, 1886; Neaverson, 1930, 1937; Somerville, 1979; Walkden and Davies, 1983; Davies et al., 1989; Davies et al., 2004; Juerges et al., 2015). These two closely situated, coeval platforms provide an excellent opportunity to assess the importance of localised, basinal and global controls on sedimentation, such as proximity to a landmass and volcanism, on carbonate depositional processes in comparison to significant changes in global climate and eustatic sea level resulting from the onset of the LPIA.

\section{GEOLOGICAL SETTING}

During the Viséan, northern England was undergoing pulsed extension (Fraser and Gawthorpe 2003) with carbonate platform growth established $\sim 245 \mathrm{Ma}$ on the footwalls of rotated fault blocks (Ebdon et al., 1990; Fraser et al., 1990). During the Holkerian, the margins of these platforms began to steepen as the result of topographic differentiation between shallow water carbonate platforms and hanging wall basins, with high rates of extension along basement-involved faults (Schofield and Adams, 1985; Fraser and Gawthorpe, 2003). In the seismo-stratigraphic framework developed for the Carboniferous of the Pennine Basin (Ebdon et al., 1990; Fraser et al., 1990; Coward, 1993; Fraser and Gawthorpe, 2003; Figure 2), the Late Holkerian to mid-Asbian are equivalent to Stage EC4. The mid to late Asbian is equivalent to Stage EC5 (Ebdon et al., 1990; Fraser et al., 1990; Fraser and Gawthorpe, 2003) and is the focus of this paper. The North Wales Platform was a land-attached carbonate platform (approximately $1200 \mathrm{~km}^{2}$ ) located in the East Irish Sea Basin. The Derbyshire Platform was a distally land attached extension of the East Midlands Platform approximately $100 \mathrm{~km}$ east. The platform extends from Castleton (Locality A) in the north to Matlock (Locality C) in the south (approximately $400 \mathrm{~km}^{2}$ ) and the whole East Midlands Platform is approximately $5000 \mathrm{~km}^{2}$. On the Derbyshire 
Platform, Stage EC5 is equivalent to the Bee Low Limestone whilst the lithostratigraphic name for EC5 on the North Wales Platform is the Loggerheads Limestone (locally the Great Orme Limestone; Figure 2). During the Asbian (337.5 to $333 \mathrm{Ma}$; Rohde, 2005) the study area was located in the Tropical Zone at approximately $336^{\circ} \mathrm{E} 14^{\circ} \mathrm{S}$ (Piper, 1991 ; Cocks and Torsvik, 2011). The outcrops used in this study are situated on the margin of the Derbyshire Platform around Locality A, near to Castleton, East Midlands, and in proximity to the northern margin of the North Wales Platform, which outcrops as the Great Orme (Locality D) and Little Orme (Locality E) headlands near Llandudno, Conwy (Table 1a; Figure 1; Figure 3). Parallel to the northern margin of the North Wales Platform on the Isle of Anglesey, near Penmon Point (Locality F), facies were also mapped and sampled. Outcrops of the western margin of the Derbyshire Platform are near to Buxton and Hartington (Localities B, I and K). The North Wales platform interior was studied around Cefn Mawr and Llangollen (Localities H and G), 20 and $40 \mathrm{~km}$ south of the margin.

\section{METHODS}

Facies were mapped at a kilometre scale and logged at a scale of $1 \mathrm{~cm}: 50 \mathrm{~cm}$ across the Derbyshire and North Wales Platforms using natural outcrops, disused quarries, and core (25 sections) (Table 1a). 21 published stratigraphic sections were also used to support observations made from core and outcrop (from Stevenson and Gaunt, 1971; Aitkenhead et al., 1985; Table 1a). No core has been acquired around Localities D, E and F, so all observations of the North Wales Platform were made from outcrop and petrography. Additional localities, which were not logged but are described herein, are also noted (Table 1b). 125 polished and covered sections were prepared and half stained with Alizarin Red S and potassium ferricyanide to distinguish ferroan- and non-ferroan calcite and dolomite (after Dickson, 1965), and porosity. Samples were analysed using transmitted light microscopy and microfacies were classified using the Dunham classification scheme (Dunham, 1962). Quantification of components (matrix, cements, and allochems) was achieved by point counting 300 points of 30 samples using Petrog ${ }^{\mathrm{TM}}$. Micropalaeontological analyses of benthic, predominantly fusulinid, foraminifera and calcareous algae were conducted on 29 of the thin sections. A FEI QUANTA 650 scanning electron microscope was used to investigate features potentially below the resolution of transmitted light microscopy. A Bruker D8 Advance X-Ray Diffractometer was used to identify the mineral assemblage of 37 samples of platform exposure-related facies, and of 16 samples of limestone and siliciclastic-influenced bedrock.

\section{RESULTS}

\section{Depositional Environments}

Six depositional environments, plus igneous rock formations and exposure-related facies, were identified from outcrop, core, and petrographic analysis of the exposed Asbian succession (Bee Low Limestone on the Derbyshire Platform and Loggerheads Limestone on the North Wales Platform). These are summarised in Table 2, briefly described below and in Figure 4.

\section{Slope/foreslope Depositional Environment}

The foreslope/slope depositional environment does not crop out on the North Wales Platform. On the Derbyshire Platform, it comprises two principle facies. On the northern and western margins, a poorly sorted conglomerate, comprising sub-rounded intraclasts of skeletal wack/packstone $(0.5-10 \mathrm{~cm}$ diameter $)$, peloids and fragments of crinoids, bryozoa and brachiopods, forms beds that dip at approximately $30^{\circ}$ northwards, towards the Edale Basin (Figure 5A). The fragments and clasts are micritised and coated by $1-10 \mathrm{~mm}$ thick radiaxial fibrous calcite (Figure 5B; Figure 6A; Table 2; e.g. Bathurst, 1959). Brachiopod moulds are partly-infilled by calcite cement, with sediment at the base of the moulds inclined at approximately $30^{\circ}$. On the northern and western margins, limestone blocks that are several metres in diameter are found. Clean, skeletal grainstones are particularly abundant on the western margin of the Derbyshire Platform (Figure 6B). On the southern margin, beds of skeletal wacke/packstone are locally contorted and dip basinwards at approximately $20^{\circ}$ (e.g. Locality 17) (Figure 5C and 5D). 
On the northern platform margin, geopetal textures suggest that the steep bedding angle is a true representation of paleo-sedimentary dip. The thick radiaxial fibrous cements that bind clasts and grains typically form syn-depositionally as a result of high energy (wave and storm-driven) flux of seawater (Kendall, 1985; van der Kooij et al., 2010) and can bind non-cohesive material to maintain a steep slope angle (e.g. Kirkby, 1987; Kenter 1990; Della Porta et al., 2003; Bahamonde et al., 2004). The coarse grain size of clasts and skeletal grains, high skeletal diversity and poor sorting is suggestive of short-lived, episodic sediment transport, from a shallow water setting, in response slope failure by gravity or fault movement. The northern margin of the Derbyshire Platform is $<1 \mathrm{~km}$ north of an array of E-W trending faults, thought to be associated with the Edale Fault (Fraser et al., 1990; Fraser and Gawthorpe, 2003; Figure 3), and seismic activity along this fault might have triggered mass transport of sediment on the platform margin. Contorted, more shallow-dipping beds and an absence of large clasts on the southern margin of the Derbyshire Platform are suggestive of soft sediment deformation but a much shallower slope angle than on the northern margin. The slope/foreslope of the North Wales Platform has either been eroded or is not exposed, with the palaeo-platform margin interpreted from seismic data to be offshore of the present coastline (Figure 1; Floodpage, 2001; Pharoah et al., 2018).

Platform Margin Depositional Environment

The Platform Margin depositional environment comprises two principle facies which are observed on the margins of the Derbyshire and North Wales Platforms:

1) Carbonate mounds, which occur as massive, dome-shaped structures, have a distinct core, intramound, and flank facies that dip at approximately $30-40^{\circ}$ (Figure 7). They are typically up to $50 \mathrm{~m}$ wide and $9 \mathrm{~m}$ high and are spaced a few hundred meters to kilometres apart. The core is cemented and dominated by crinoids, brachiopods and bryozoa. Vugs, which are $<10 \mathrm{~cm}$ wide, are common and can be lined by radiaxial fibrous calcite cement. The intramound facies are bioclastic peloidal wackestone and packstone with a diverse skeletal assemblage (fragmented bryozoa, brachiopods, corals, foraminifera, dasycladacean algae including Koninckopora) and a high volume of micrite (Figure 6C - D). No microbial binding was observed in outcrop, thin section, or under SEM. Flank facies include brachiopods floatstones and crinoidal grainstones (Figure 7B, 7C).

2) Skeletal grainstones typically comprise light- or reddish-grey stacked beds and form discontinuous bodies that pinch out in one or more directions. They are either isolated, sheet-like or cross-bedded bodies $(<100 \mathrm{~m}$ wide, $5 \mathrm{~m}$ thick) within thick ( $>2 \mathrm{~m}$ ), tabular limestone beds. They dip and pinch in numerous directions (Type A), or downlap onto carbonate mounds ( $<10 \mathrm{~m}$ wide, $<10 \mathrm{~m}$ thick) and dip obliquely to the mound interface (Type B or "intermound"). Both types of skeletal grainstone are coarse grained ( $>1 \mathrm{~mm})$ and dominated by crinoid ossicles and large corals $(20-30 \mathrm{~cm})$. The skeletal assemblage is moderately sorted $(0.2-2 \mathrm{~mm})$, and includes disarticulated crinoids, and fragmented brachiopods, bryozoa, foraminifera, undifferentiated skeletal fragments, corals, and demosponge, dasycladacean algae, including Koninckopora.

Carbonate mounds are highly characteristic of the Viséan (Nichols, 1961, 1965; Bancroft et al., 1988; Horbury, 1992; Gutteridge, 1990; Gutteridge, 1995; Somerville, 2003). They most closely resemble the Type 2 mounds of Somerville (2003), interpreted to accrete from a crinoid - bryozoan - brachiopod core with abundant cemented micro-peloidal micrite such that structural support by organisms was short lived, and the mound was rapidly cemented. They are the most important constructive facies on the platform margin, but their spacing indicates that they did not form a continuous rim but rather formed isolated structures, or potentially, in slightly deeper water $(10-20 \mathrm{~m})$ basinward of the margin (Harwood, 2005). Some allochems were dissolved and solution-enhanced to form irregular-shaped vugs; since marine cements line these vugs they are inferred to have formed soon after deposition. It is possible that algae stabilised soft sediment in localised, relatively shallow and restricted or protected areas, allowing mound colonisation but there is limited direct evidence for microbial activity ('cryptic evidence' of Pickard, 1996). Following initial colonisation, bryozoa built upwards, trapping transported, fragmented skeletal grains such as crinoids and brachiopods, which were then rapidly cemented to form the intramound facies ('bulk facies' of Bancroft et al., 1988). Opportunistic brachiopods and crinoids then colonised the flanks and top of the mound as it grew into areas of relatively shallow water, (e.g. Bancroft et al., 1988 and Somerville, 2003). 
The clean texture with diverse, moderately sorted skeletal grains within the skeletal grainstone facies are indicative of a higher energy depositional setting in clear, shallow water. The preservation of cross-bedding is also indicative of high depositional energy and the pinching geometry of beds is typical of sediments influenced by wavedriven currents (Rankey and Reeder, 2012). These grainstones are interpreted to be platform margin sand-bars deposited on seaward facing platform margin, where the most agitated environments occurred, forming pinching beds shaped by multidirectional wave-energy (see: Rankey et al, 2006; Rankey and Reeder, 2012).

\section{Platform Interior Depositional Environment}

The platform interior depositional environment mostly comprises thick $(0.5->3 \mathrm{~m})$ tabular, beds that are laterally continuous for hundreds of metres (Figure 8A). The platform interior comprises a diverse, moderately sorted fine-grained skeletal assemblage of varying abundance (Figure 6E; Table 2) (brachiopods, crinoids, bryozoa, dasycladacean algae, demosponge, gastropods and a diverse range of benthic foraminifera (e.g. Figure 9) with several sub-facies:

1) Mounds which are internally uniform (i.e. lacking a core, intramound, and flank facies) with a low height-to-width ratio (20 $\mathrm{m}$ wide and $15 \mathrm{~m}$ high) and some weak bedding. They often overly a grainstone body and comprise tightly-stacked, thin-branched (branches approximately $1-2 \mathrm{~cm}$ in diameter) Siphonodendron corals (colonial rugose coral), some of which are fragmented, within a micrite matrix (Figure 8B).

2) Skeletal grainstones, which are sporadically interbedded and laterally discontinuous, with beds $<0.3 \mathrm{~m}$ thick and 3-10 m wide. On the Derbyshire Platform, these skeletal grainstones are only observed in drill core from boreholes (e.g. Localities 2, 4 and 8; Table 1a).

3) Fine-grained skeletal wacke/packstone with a diverse, highly fragmented skeletal assemblage and diffuse mottling. This includes the Tollhouse Mudstone Bed, a distinct lithostratigraphic unit on the North Wales Platform which is up to $3.5 \mathrm{~m}$ thick, that comprises tabular, parallel beds of skeletal wackestone and mudstone, interbedded with skeletal packstone. Tubular and nodular structures (cmscale diameter and length) occur at the base of some beds. The matrix is dark-grey/brown containing white skeletal fragments and $\mathrm{cm}$-scale brachiopods. The microfossil assemblage comprises sub-mm diameter benthic foraminifera, brachiopods, crinoids, bryozoa, dasycladacean algae, and corals, with trace serpulidae.

Overall, parallel bedding, high skeletal diversity, and the high degree of grain fragmentation is suggestive of moderate to locally high energy deposition in an unrestricted subtidal environment within the platform interior. Mottling is interpreted to be bioturbation, although there is no preservation of the trace-making organism; it is most likely to be Phycosiphon or a similar feeding trace which selectively ingests clay-grade material, and occurs in a range of bathymetric conditions, possibly polychaetes (Gingras et al., 2002). The diffuse edges of the traces suggest that the sediment remained soft and unlithified for a long period. On sedimentary evidence alone, it is difficult to confidently estimate water depth within skeletal packstone facies, but could reflect sedimentation at or around fair weather wavebase. Tubular and nodular structures are burrows, indicating soft sediment reworking of submarine sediment, and suggesting low to moderate energy conditions and gentle winnowing of sediment. The small grain-size and abundance of micrite within skeletal wackestone facies, however, including the Tollhouse Mudstone Bed is indicative of deposition under moderate to low energy conditions by gentle winnowing with abundant dasycladacean algae indicative of water depths of less than $10 \mathrm{~m}$ (Jones, 2006).

Platform interior, coral-dominated mounds are rarely described from UK Mississippian platforms (e.g. Aretz and Herbig, 2003) and their low abundance is suggestive of niche environmental conditions. Rugose corals have been described from Carboniferous mounds (e.g. Shen and Webb, 2005; Gong et al, 2012). However they only rarely form the main frame-building organism within similar coral biostromes that have been recognised within the upper Viséan of the Dinant Platform (e.g. Aretz and Chevalier, 2007). A high abundance of tightly packed colonial corals is suggestive of localised, higher energy conditions compared to marginal mounds since the skeletal framework indicates an adaptation to high-energy waves or currents. This is consistent with the association of the build-ups with underlying grainstones and fragmentation of corals within the main structure. Corals may have attached to a microbially-stabilised substrate, similar 
to marginal mounds, on an area of relatively high topography, and thus an environment with shallower, more turbulent waters.

\section{Peritidal Depositional Environment}

The peritidal depositional environment is extremely rare and presents as stratiform, but slightly crinkled, and locally pinnacle-shaped microbial boundstone. It is observed at only two localities on the North Wales Platform (Locations $\mathrm{G}$ and $\mathrm{H}$ ). The facies is typically no more than $0.25 \mathrm{~m}$ thick (Figure 8D) and includes laminae of alternating yellow-coloured cemented mudstone and white unconsolidated carbonate mud. XRD indicates that the facies comprises $82.8 \%$ calcite, $12.9 \%$ muscovite, $1.8 \%$ quartz, $1.2 \%$ halite, $0.7 \%$ barite, and $0.5 \%$ haematite. The fine lamination of this facies implies an area of very shallow water and the presence of minor halite suggests that at some point the environment was evaporitic. The crinkled nature of the beds and carbonate mud composition is suggestive of a microbial origin. The presence of terrigenous grains indicates the presence of siliciclastic material, accumulated and trapped because the laminite grew in very shallow water.

\section{Exposure -related Facies}

Exposure-related facies can be categorised into four types, all of which are usually observed associated with each other (Figure 10a): i) pitted/mamillated surfaces (Type A), (ii) tubular and nodular/brecciated horizons (Type B), (iii-v) unconsolidated muds and clays (Type C), and coals (Type D). These surfaces punctuate strata 18 to 49 times per $100 \mathrm{~m}$ of strata on the North Wales Platform and 8-18 times per $100 \mathrm{~m}$ on the Derbyshire Platform, and increase in frequency vertically (Manifold et al. 2020).

Type A surfaces consist of smooth, mamillated bedding surfaces with a wavelength of $0.2-1 \mathrm{~m}$, and up to $10 \mathrm{~cm}$ deep, sometimes cross-cutting sedimentary features or infilled by Type $C$ exposure facies. These surfaces can be traced laterally for tens of metres but are discontinuous over hundreds of metres. They are frequent, occurring on average every 10-15 m, but increasing in frequency towards the top Asbian, particularly on the North Wales Platform. In thin section, the platform interior limestones which directly underlie these surfaces are sometimes partly dissolved and replaced by coarse, sparry cements (Figure 6F).

Type B surfaces principally outcrop on the North Wales Platform, are $<1.5 \mathrm{~m}$ thick and extend laterally for a few hundred metres; occurrences on the Derbyshire Platform are much less common, extensive for less than $100 \mathrm{~m}$, and usually $<1 \mathrm{~m}$ thick. They comprise nodules of skeletal packstone, $2-5 \mathrm{~cm}$ in diameter and are clast-supported, with interclastic sparite cement or unconsolidated sediment. This facies is underlain by beds of a similar appearance but with subvertical tubular structures, typically $3 \mathrm{~cm}$ wide and $25 \mathrm{~cm}$ long.

Type $\mathrm{C}$ surfaces are $0.05-0.8 \mathrm{~m}$ thick, often with a lenticular geometry, and can be red, brown, or yellow in colour. They are laterally extensive for tens to a few hundred meters, occurring between beds of platform top strata, Excluding calcite, the average composition of this facies is $32.1 \%$ kaolinite, $30.2 \%$ muscovite, $30.2 \%$ quartz, $7.5 \%$ other minerals, principally haematite and feldspars, with minor barite and pyrite. This facies is particularly abundant on the North Wales Platform around Locality D, and is also documented westwards around Anglesey (Howells, 2007). On the Derbyshire Platform, it is not seen in outcrop, but a few examples are well-preserved in core, one sample of which contains plant material and quartz nodules $(<2 \mathrm{~cm}$ ) (Figure 10a(iv)). Type D, coals, form around Localities $G$ and $H$ (Figure $4 \mathrm{~d}$ ) as three bands $<1 \mathrm{~m}$ thick.

The smooth, mamillated Type A surfaces have been interpreted to form beneath a layer of soil (Walkden, 1974), although soil is rarely preserved on the Derbyshire Platform, or by dissolution by stem-flow around trees (Vanstone, 1996). Where soil is not present, these surfaces may be confused with compactional bedding surfaces and they are most confidently identified when they cross-cut sedimentary features or are associated with another platform exposure-related facies. The cements directly below the surface of Type A facies are mostly formed during meteoric diagenesis, within the meteoric phreatic realm (Walkden and Williams, 1991; Juerges et al. 2016).

Type B cemented nodular limestone is characteristic of calcrete, which forms as limestone precipitates around soil particles and roots to give a brecciated appearance (Durand et al., 2010). The tubular structures which underlie Type $\mathrm{B}$ surfaces are interpreted as burrows, rather than rootlets, because they are long, subvertical, lack a consistent structure and contain a coarser grained sediment than the surrounding matrix, which suggests reworking and sediment mixing by living organisms. Their consistent diameter and relatively short length is also inconsistent with rootlets, which often have 
varying diameters and can be metres in length (Klappa, 1980). Unlike the diffuse, mottled bioturbation within the platform top limestones the excellent preservation of these open burrows suggests the sediment was firm, probably partly cemented, suggesting a relatively shallow-water depth compared to the majority of the platform interior. These traces are most likely formed by shallow deposit-feeding and dwelling crustaceans which colonised the substrate in shallow seas prior to platform exposure.

The abundance of clay and the soft texture of Type $C$ beds, along with their association in outcrop with Type B facies (calcretes) and the presence of plant material and terrestrially-derived minerals (quartz and muscovite), is consistent with them being palaeosols. Their colour is likely linked to the varying extent of iron oxidation of haematite. Type D facies, coal, forms in a narrow area in the southernmost part of the study area on the North Wales platform, and reflects a terrestrially-influenced, swampy environment close to the palaeo-shoreline on the Wales-Brabant Massif.

\section{Extrusive Igneous Rocks}

There were two main volcanic centres on the Derbyshire Platform during the Viséan, near Localities B and C (Figure 12; Arnold-Bemrose, 1907; Walkden, 1972), with two types of extrusive igneous rocks identified from outcrop and core. Type A is dark-coloured, mafic (pyroxene-dominated) and fine grained, sometimes contains calcite-filled vesicles $(<7 \mathrm{~mm})$. In outcrop, near Locality 13 , they have a columnar habit but ordinarily they are massive, bed-parallel and vesicle-rich and have an irregular contact with underling limestone (Figure 10a(vi)). Type B comprises multicoloured, friable clays in core (Figure 10a(vii), and dark coloured clays in outcrop. Published core descriptions indicate that this facies occurs throughout the Asbian at bedding contacts (Walkden, 1972; Cox and Bridge, 1977; Cox and Harrison, 1980; Bridge and Gozzard, 1981; Harrison, 1981). When their occurrence is mapped, the facies shows a NW-SE distribution over the Derbyshire Platform (Figure 12). Beyond the perimeter of this mapped distribution, volcanic ash is not recorded, including on the North Wales Platform.

The fine, pyroxene-rich composition of the Type A lithology, as well as the abundance of calcite-filled vesicles, suggests that they are amygdaloidal basalts. Their occasional columnar habit indicates that the rock locally contracted upon cooling to form vertical joints (e.g. Haldar and Tišljar, 2014). Over forty igneous bodies of this type are preserved in Viséan strata, described as 'scutulum-type' shields (i.e. they formed during a singular eruption; Waters, 1981; de Silva and Lindsey, 2015). The irregular, interfingering contact between the basalts and the limestone suggests magma eruption was syndepositional, or at least pre-lithification (Figure 10b(i)). Although most igneous extrusive beds are interpreted to be deposited subaerially (Waters, 1981), the interaction of lava and unlithified sediment suggests that some were submarine. Type B volcanic facies have clay-sized grains which are suggestive of volcanic ash (consolidated as tuffs). Dark bands observed in outcrop comprise K-bentonite clays (“clay wayboards"; Trewin, 1968; Walkden, 1972; 1974) which are an alteration product of volcanic ash, suggesting that coloured and dark clays are of the same origin.

\section{Siliciclastic Depositional Environment}

No siliciclastic facies were observed on the Derbyshire Platform. On the North Wales Platform, dark grey mudrock forms beds, $\sim 1$-metre in thickness, between 1 to 5 metre thick limestone beds (Locality G; Figure 10c) and contain interbedded coal at Locality H. Mudrocks contain no marine bioclasts and often, but not always, overly mammilated (Type A) exposure surfaces. They have sharp lower and upper boundaries with interbedded limestone that are not cross-cut by burrows.

The absence of marine bioclasts within the mudrock suggests it is terrestrial, and its limited distribution, within the Loggerheads Limestone on the southern margin of the North Wales Platform (Location H), is suggestive of riverine influx of mud on the shoreline with the Wales - Brabant Massif. In particular, the association with coal, lack of macroor microfauna and siliciclastic composition is suggestive of deposition in a low energy, swampy, marginal marine setting and a humid climate. Where mudrocks sharply overly limestone, and there is no intervening emergent surface, it is possible that the mudrock is marine; where it overlies an emergent surface then it could be terrestrial. Sharp upper boundaries indicate that once the clastic incursion event was over, the carbonate factory restarted, implying that changes in relative sea level were minor and certainly insufficient to shut down the carbonate factory by drowning.

Although the Derbyshire Platform was situated a similar distance from the shoreline of the Wales-Brabant Massif as the North Wales Platform (approximately $25 \mathrm{~km}$, Figure 1), siliciclastic sediments did not reach the Derbyshire 
Platform. This is likely because the intervening basin, the Widmerpool Gulf (Figure 3), would have trapped northerlyprograding siliciclastic sediment (Trewin and Holdsworth, 1972).

\section{Biostratigraphy}

The Tollhouse Mudstone crops out at the base of the Great Orme / Loggerheads Limestone (Figure 2) and is middle to Late Asbian age (EC5) (Biozones Cf6y1-2; after Conil et al., 1991 and Somerville et al., 2008). The Loggerheads Limestone contain a typical Asbian microfaunal assemblage comprising dasycladacean green and coralline red algae (e.g. Coelosporella spp., Koninckopora inflata and Ungdarella spp.), palaeoberesellids (e.g. Kamaenella spp.), calcispheres (e.g. Calcisphaera laevis and Calcisphaera pachysphaerica) and benthic foraminifera including Archaediscus angulatus, Bibradya spp., Cribrospira panderi, Cribrostomum spp., Endothyra phrissa, Eostaffella prisca, Forschia spp., Lituotubella glomospiroides, L. magna and Omphalotis omphalota. On macrofaunal evidence, the Loggerheads Limestone is interpreted to have been deposited within a shallow, platform interior setting. The abundance of Koninckopora, Ungdarella and palaeoberesellids, as well as endothyroid foraminifera with multi-layered tests, specialised chamber partitions and cribrate apertures (i.e. Bibradya spp., Cribrospira panderi, Cribrostomum spp. and Nevillea spp.) and large thick-walled forschiids (Forschia spp.) within this unit suggest deposition in high-energy pseudo-algal meadows marginally below to above fair-weather wave base, in water depths of approximately 5 to $15 \mathrm{~m}$ (e.g. Gallagher, 1998; Gallagher and Somerville, 2003).

On the Derbyshire Platform, both the Bee Low Limestone and basal section of the overlying Monsal Dale Limestone (Brigantian) contain a typical Asbian microfaunal assemblage comprising dasycladacean green algae, palaeoberesellids, calcispheres and benthic foraminifera similar to that described the North Wales Platform. The texture and fabric of the Bee Low Limestone has been interpreted to reflect winnowing and bioturbation in a moderate energy setting, at or around, fair-weather wave base. The abundance of the foraminifera Howchinia spp., Palaeotextularia spp., Pseudoendothyra spp. (including P. struvii), Tetrataxis conica and Vissariotaxis spp. in samples from both the northern and north-western platform margin (Localities 11, 18, I) and platform interior (Locality J) of the Derbyshire Platform are consistent withrelatively low hydrodynamic energy (e.g. Gallagher, 1998; Gallagher and Somerville, 2003) and may suggest deposition below fair-weather wave base (between $15 \mathrm{~m}$ and $25 \mathrm{~m}$ ). The western margin of the Derbyshire Platform is interpreted to be shallower, higher energy (e.g. Locality K) than the northern or southern margin on the basis of the abundance of dasycladacean green algae.

\section{Asbian - Brigantian boundary}

The boundary between the top of the Asbian and the base of the Brigantian is recognised across the Derbyshire and North Wales Platform, in both outcrop and core (Figure 11). It usually manifests as an irregular, pitted surface that resembles Type A facies (of the Exposure-related facies), but pits are often deep (up to 1 metre), with a greater depth / width ratio than other mamillated surfaces. The surface can usually be walked out over the length of an outcrop, and on the North Wales Platform is also associated with Type C (usually reddened) palaeosols). On both platforms, there is a marked change of facies across the Asbian - Brigantian boundary, from clean, light coloured packstones with frequent emergent surfaces to darker, more chert rich packestones with abundant Gigantoproductids, and fewer emergent horizons (Manifold, 2019). On the Derbyshire Platform, the Asbian - Brigantian boundary is commonly also picked lithostratigraphically at the top of the Lower Matlock lava, whilst the top Asbian in the Eyam and Duffield boreholes is defined at the top of an agglomerate and dolerite sill, respectively (Chisholm et al., 1983; Waters, 2009).

\section{DISCUSSION}

\section{Controls on Platform Architecture}

An E - W oriented correlation using outcrop data from across the Derbyshire and North Wales Platforms was constructed using the biostratigraphic data (Figure 13). Biostratigraphic correlations have been published previously (Vaughan, 1905; Garwood, 1913; Conil et al., 1979; Strank et al., 1981; Waters et al., 2009) and the new data from this 
study supplements that interpretation. In particular, it differentiates a significant period of platform exposure and absence of carbonate deposition at the Asbian - Brigantian boundary, which was used as a datum for correlation because it can be confidently correlated across both the platforms.

\section{Palaeo-wind direction}

The dip angle of beds and the geopetal textures within slope facies from the northern margin of the Derbyshire Platform indicate a palaeo-dip on the platform slope of $30^{\circ}$. This is consistent with previous interpretations (Broadhurst and Simpson, 1967; Simpson and Broadhurst, 1969; Broadhurst and Simpson, 1973; Fraser et al. 1990; Gutteridge, 1991; Harwood, 2005), but is shown here to have resulted from stabilisation of the remobilised debris, as well as microbial boundstones (Harwood, 2005), by syn-depositional radiaxial fibrous calcite cementation. These cements precipitate as a result of wave and storm- facilitated seawater flux (Kirkby, 1987; Kenter 1990; Della Porta et al., 2003; Bahamonde et al., 2004; van der Kooij et al., 2010). Miller and Grayson (1982), Smith et al., (1985) and Gutteridge (1987) all interpreted the Derbyshire Platform to be a southward-dipping fault block, but Schofield (1982) and Gawthorpe and Gutteridge (1990) infer the northern margin to be leeward. On the north and west of the Derbyshire Platform, platform margin build-ups might have developed in response to footwall rotation, basinal currents or other environmental controls, and this combined with preferential cementation would have contributed to steepening of the platform margin. However, these features are also consistent with a windward-facing margin; a feedback mechanism can be interpreted between the moderately high energy setting, optimal carbonate productivity and platform margin steepening by cementation. In contrast, the southern margin of the Derbyshire Platform shows no evidence of extensive marine cementation, all measured sedimentary dips were less than $20^{\circ}$, and sediments were dominated by slumped skeletal grainstone facies, with no evidence of debrites. These features are all suggestive of a leeward margin. In particular, the absence of marine cements on the southern platform margin means that coarse sediment could have been transported southwards, with slumping of cohesive floatstone-rudstones down-slope.

The interpretation of a NW to SE directed wind direction seems counter-intuitive given the palaeogeographical setting; the study area was south of the equator during the late Viséan and global wind direction would therefore be expected to be from east to west (i.e. south - east trade winds). However, the Pennine Basin was a protected seaway, with a narrow eastward connection to the Rheic Ocean, witha large landmass to the north (Cocks and Torsvik, 2011). Combined with Variscan mountain-building to the south of the study area, perturbations to the global wind patterns could have developed, and might have created a dominant NW to SE wind direction in the southern Pennine Basin. This is supported by mapped distribution of wind-dispersed volcanic ash (Figure 12).

\section{Controls on platform margin morphology}

Carbonate mounds crop out every few hundred metres to kilometres along the northern and western margin of the Derbyshire Platform and the northernmost outcrop of the North Wales Platform, with flanking and inter-fingering grainstone shoals. The western margin is dominated by extensive $\left(<500 \mathrm{~m}^{2}\right.$ wide, $<5 \mathrm{~m}$ thick) clean Koninckopora grainstones. The northern margin of the Derbyshire Platform is embayed, with each embayment being approximately 1 $2 \mathrm{~km}$ wide, separated by promontories that are a few hundred metres wide, in agreement with Ford (1987) and Harwood (2005). The western margin of the Derbyshire Platform is more linear, even though it is also windward-facing. The processes governing the morphology of the platform margin cannot be confidently determined, but it is tentatively suggested that embayments formed because of mass wasting or episodic collapse of the slope/margin as a result of movement along the Edale Fault. Embayments could also have formed as a result of syn-depositional, wave-driven, erosional processes, although the western margin may be expected to host embayments in this scenario. In contrast, the western margin is not underlain by a deep-seated crustal lineament, and it appears to retain a linear profile.

The Derbyshire Platform has previously been described as rimmed (e.g. Smith et al., 1985; Gutteridge, 1991) but the dispersed distribution of mounds and shoals suggests that build-ups were less laterally continuous than previously assumed. The depths at which mounds grew is also unclear; Harwood (2005) suggested water depths of 10 to 20 metres. Mound growth might have been assisted by wave-driven circulation of sea-water; displacement of corals from mounds on the northern margin on the Derbyshire Platform (e.g. Locality 15), and reworking into shoals implies episodic storm-related sedimentation. If so, this provides further support for this being a higher-energy, windward- 
facing margin than the southern platform margin. The basinward margin of the North Wales Platform is not present, because of erosion and the position of the present day shoreline.

Grainstone shoals on the northern margin of the Derbyshire Platform are not laterally continuous, as described in many modern, open ocean-facing platforms (Rankey, 2006; Rankey and Reeder 2012). Instead, they form bedded units up to $10 \mathrm{~m}$ thick that extend laterally for up to $50 \mathrm{~m}$, passing into parallel-bedded platform interior facies. This would suggest that grainstone bodies were spatially restricted, perhaps because mounds flourished first, limiting shoals to intermound areas. Mounds may have become well established because local environmental conditions favoured microbial stabilisation of the mound core, in localised, slightly protected shallow waters. Alternatively, mounds developed within protected, lower energy areas between shoals. Embayments along the platform margin may have also spatially restricted shoal development and affected margin bathymetry; Broadhurst (1973) suggested undulating bathymetry led to faunal variation across the margin, but this was not observed here and the macrofauna (brachiopods, bryozoa, crinoids, Siphonodendron corals) occur at a range of water depths and are consistent with low levels of environmental stress (Ryland, 1970; Brand et al., 1989; Billing, 1991; Fedorowski, 2008).

On the western margin of the Derbyshire Platform, the shoals are laterally extensive ( $>3 \mathrm{~km}^{2}$; e.g. Locality $\left.\mathrm{K}\right)$. They are interpreted to have been deposited in shallower, higher energy, water than the northern margin, because of their cleaner texture and the abundance of Koninckopora, which indicate water depths of less than $10 \mathrm{~m}$ (Jones, 2006). The linear morphology of the western margin suggests that there were fewer embayments and therefore the geometry and distribution of the shoals was more likely controlled by the geometrical architecture of the margin, and resultant bathymetric variations. This interpretation contrasts with Gawthorpe and Gutteridge (1990) who interpreted that shoals developed during marine transgressions, suggesting a temporal control on sedimentary architecture.

\section{Controls on facies distribution on the platform top}

The platform interior facies of the Derbyshire and North Wales Platforms are characterised by bedded limestones punctuated by exposure surfaces. Between these surfaces, sedimentary texture and macrofaunal assemblages indicate a moderate - energy, subtidal platform interior setting, with deposition at, or potentially below, fair-weather wave base. These facies then pass up into shallower, higher energy, wave-influenced facies capped by mamillated surfaces and/or calcretes or palaeosols. Peritidal facies are rarely preserved in Asbian strata, with only one clear example (Figure 8D; North Wales Platform), either because they never formed, perhaps due to a rapid fall in relative sea-level (e.g. Wright, 1986; Heckel, 1990; Wright, 1992), or because they were deposited and then removed by erosion. In contrast, south of the Wales - Brabant Massif, peritidal facies were common at this time (e.g. Poty et al., 2014). This marked constrast is facies between the platforms that north and south of the Wales-Brabant Massif is surprising if sediment-stacking is indicative of glacio-eustatic cycles (Wright and Vanstone, 2001; Poty, 2016) 0. The very rare occurrence of peritidal sediments amongst all the localities in this study suggests, therefore, that they almost never formed, and the laminites identified on the North Wales Platform are likely to reflect areas of locally high topography, providing a shallow-water environment for microbial organisms to colonise.

Although there is microfaunal evidence that deposition was in slightly deeper water on the Derbyshire Platform, compared to the North Wales Platform, there is no significant difference in carbonate facies between the two platforms. This is despite extensive syn-depositional volcanism on the Derbyshire Platform, and the proximity of the Wales - Brabant Massif to the North Wales Platform. The exception to this is towards the shoreline of the North Wales Platform, where coal and mudrock becomes common above exposure surfaces and mudrock is interbedded with limestone, creating more complex vertical stacking than further offshore. Overall, the limitation of interbedded mudrock to the southern margin of the North Wales Platform suggests that the influx of clastic sediment from the Wales - Brabant Massif did not supress carbonate productivity substantially across most of the North Wales Platform during the Asbian. This might be because the platform interior experienced moderate to high energy conditions, as (demonstrated by the high abundance, high diversity foraminiferal and algal assemblage such as Koninckopora, Ungdarella, palaeoberesellids, endothyroid foraminifera, Bibradya spp., Cribrospira panderi, Cribrostomum spp. and Nevillea spp., Forschia spp.), facilitating distribution of mud. Alternativelyclastic sediment supply to the shoreline was localised and of insufficient volume to impact carbonate productivity.

Logging and mapping of facies distribution shows that all platform interior facies can be positioned adjacent, parallel, and/or interbedded with one another (Figure 4; Manifold et al., 2020). Lithofacies and exposure surfaces/facies 
can rarely be walked out for more than a few hundred metres in outcrop across both platforms. Manifold et al. (2020), argued that the lack of ordering/cyclicity was not because of missing facies, but because of the differing arrangement of facies between exposure events across the study area. Based on stratigraphical and statistical forward modelling, Manifold et al (2020) interpreted facies on the Derbyshire and North Wales Platforms to be a mosaic (after Burgess and Pollitt, 2011 and Burgess, 2016). This conclusion is supported by the laterally discontinuous nature of exposure surfaces and facies in outcrop and suggests that factors other than relative sea-level fluctuation, such as changes in productivity, water quality, and self-organisation of strata, controlled facies distribution (Wright and Burgess, 2005). For example, platform interior float-rudstone facies, with an abundant and diverse assemblage of bryozoa, brachiopods, crinoids, and Siphonodendron corals, could have been established in response to optimal environmental conditions (Ryland, 1970; Brand et al., 1989; Billing, 1991; Fedorowski et al., 2008). Fluctuations in intensity of wave- and storm-driven currents, could also have been important, given the small size of both the Derbyshire and North Wales Platforms (approximately 5000 $\mathrm{km}^{2}$ ), compared to some modern platforms (e.g. the Great Bahama Bank, approximately 175,000 km²; Schlager and Ginsburg, 1981). The absence of a continuous rim on the platform margin would mean that corridors for these currents may have formed between mound communities, which would otherwise have absorbed wave energy. Overall, this has important implications for correlation of facies and interpretations of cyclicity. Shirley and Horsfield (1940) recognised that faunal bands (e.g. "Girvanella band") are not independently appropriate for correlation, because the same biota occur numerous times within the vertical succession of strata. Other biostratigraphic indicators, such as foraminifera, are long-ranging and often bridge the Asbian and Brigantian (e.g. Sevastopulo and Barham, 2014). For this reason, stacking patterns have often been used to interpret cyclicity (e.g. Wright and Vanstone, 2001; Poty, 2016), but if facies are not systematically distributed in an ordered fashion, then depositional environments cannot be used to correlate ageequivalent strata in a predictive manner. In summary, it seems unlikely that facies distribution between reliably dated, age-equivalent surfaces on the Derbyshire and North Wales Platforms, and equivalent aged strata on other platforms, cannot be predicted from deterministic models that assume ordered, systematically stacked facies.

\section{Processes controlling platform exposure}

Exposure events on the North Wales Platform are preserved as palaeokarstic surfaces, palaeosols, calcretes, and coals, and punctuate strata more frequently (18 to 49 times per $100 \mathrm{~m}$ of strata) than on the Derbyshire Platform (8-18 times per $100 \mathrm{~m}$; Manifold et al., 2020). On average, platform exposure occurred approximately every $0.04-0.2 \mathrm{My}$, based on a $4.5 \pm 1.5 \mathrm{My}$ duration for the Asbian (Rohde, 2005) and a total stratal thickness averaging at $180 \mathrm{~m}$ on both platforms. On the Derbyshire Platform, exposure events are typically mamillated surfaces and volcanic ashfalls, with palaeosols only observed in core (Locality 7; Table 1a). These exposure events are well-described and interpreted (e.g. Walkden and Davies, 1983; Walkden, 1972; 1974; Vanstone, 1998), but there has previously been no holistic attempt to explain the heterogeneity in the distribution of exposure events between the two time-equivalent platforms.

The most obvious difference between the two platforms is that volcanic ashfalls were restricted to the Derbyshire Platform because this is where the active volcanic centres were located. Furthermore, since the wind direction is interpreted to have been towards the southeast, ash would not have been transported westwards, towards the North Wales Platform. There are, however, other differences in the composition and style of exposure surfaces between the two platforms that cannot just be related to differences in volcanic activity. The abundance of well-developed calcretes on the North Wales Platform suggest arid or semi-arid conditions (Durand et al., 2010), but palaeosols, palaeokarstic surfaces, and coals are more indicative of humid or semi-humid conditions (Wright, 1980; Arnold, 2013). The presence of interbedded mudrocks near the palaeo-shoreline on the North Wales Platform also indicates that there was sufficient rainfall for rivers to transport and deposit siliciclastic sediments. These events may have also caused the water table to rise to form swamps, leading to localised formation of coal. These interpretations together suggest that on the North Wales Platform the climate oscillated between humid and arid (Wright, 1980; Falcon-Lang, 1999a and b), or spatially, with wet and dry areas. Since calcretes are commonly interbedded with palaeosols, climatic oscillations are considered more likely than localised climatic variability controlling spatial variation in the type of emergent surface. On the Derbyshire Platform, calcretes are present locally, but are thin and much less common than on the North Wales Platform, whilst palaeosols are very rare and mudrock and coals are absent. Whether mamillated surfaces formed 
beneath soils (e.g. Walkden, 1972), which were subsequently removed, or from stemflow around trees (e.g. Vanstone, 1996), the inference is that semi-arid conditions persisted on the Derbyshire Platform during the Asbian.

It is therefore possible that there was a different climate than on the North Wales Platform, with less frequent periods of humidity than further west. Alternatively, the Derbyshire Platform was not exposed as frequently, and perhaps for shorter periods, as suggested by the lower frequency of exposure surfaces on the Derbyshire Platform compared to the North Wales Platform. This could have occurred if carbonate sedimentation took place in deeper water than the North Wales Platform. It has been noted that the benthic foraminiferal assemblage (Howchinia spp., Palaeotextularia spp., Pseudoendothyra spp. (including P. struvii), Tetrataxis conica and Vissariotaxis spp.) on the Derbyshire Platform implies slightly deeper water than the North Wales Platform, which is consistent with its more distal location within the Pennine Basin, relative to the Wales - Brabant Massif. A similar conclusion, which highlighted the importance of bathymetry on exposure surface development across seven carbonate platforms of Carboniferous of the UK, was reached by Vanstone (1996). Given the similarity of facies and fauna between the two platforms, and the comparable thickness of Asbian strata (approximately 200 m; e.g. Aitkenhead et al., 1985) variation in water depths may have been driven by the natural topography of the basement and/or differential subsidence, rather than differences in carbonate productivity. The underlying basement was mapped by a gravity survey on the Derbyshire Platform and has been interpreted to strongly control the thickness of the overlying limestones (Maroof, 1976). Discerning the definite control on differential bathymetry is beyond the scope of this project, but it is perhaps logical that the distally land-attached Derbyshire Platform would have grown in deeper water than the land-attached North Wales Platform.

\section{Global climatic changes recorded in the Pennine Basin}

The Mississippian marks a critical point in Earth's history, as the proliferation of land plants led to a decrease in $\mathrm{pCO}_{2}$ and global tectonic reorganisation led to continental amalgamation, modification of ocean circulation patterns, global cooling and transition from a greenhouse to an icehouse climate (Mii et al., 1999; Smith and Read, 2000; Barham et al., 2012; Qiao and Shen, 2015; Oehlert et al., 2019). Ice advance and retreat was initiated in the Mississippian, with two principal perturbations, one in the Tournasian (approximately 355 - $350 \mathrm{Ma}$ ) and one in the late Viséan to early Serphukovian (Mii et al., 1999; Buggisch et al., 2008; Armendariz et al., 2008; Montanez and Poulsen, 2013; Godderis et al., 2017; Oehlert et al., 2019; Rosa et al., 2019). The frequency and amplitude of sea level fluctuation apparently increased after each of these events, with the transition to full icehouse conditions in the Pennsylvanian (Mii et al., 1999; Montanez and Poulsen, 2013).

In northern England and Belgium, the onset of the $2^{\text {nd }}$ phase of Mississippian glaciation has been related to preservation of high frequency cyclothems in the upper Asbian (Wright and Vanstone, 2001; Barham et al., 2012; Poty, 2016). This in part has been interpreted because of the contrast in stacking pattern to less apparently cyclic strata in the underlying Holkerian (EC4) (Schofield and Adams, 1985). There is little consensus on the duration of sea-level changes during the Asbian (Barnett et al., 2002) with estimates ranging from 0.1 My to 0.4 My (Horbury, 1989; Vanstone, 1996; Wright and Vanstone, 2001; Smith and Read, 1999, 2000). The frequency of platform exposure determined for Asbian strata in this study $(0.04-0.2 \mathrm{My})$ is broadly consistent with fifth-order glacioeustatic oscillations (after Van Wagoner et al., 1990; Barnett et al., 2002 and references therein). However, the lack of ordering of strata, lateral discontinuity of exposure surfaces (over $<500$ metres) and sharp contacts between mudrock and limestone on the North Wales Platform calls into question the evidence for cyclicity within the upper Asbian. All of these features can be interpreted as the result of autogenic processes rather than systematic changes in relative sea level. A common argument used to support rapid, glacial-drive sea level fall, is the near-absence of peritidal facies (Wright, 1992). However, the strong evidence for a semi-arid to humid climate on the North Wales Platform, and the more distal location of the Derbyshire Platform suggests that peritidal facies did not form because of the depositional setting, not as a result of rapid changes in relative sea level. In contrast, peritidal facies are well preserved within cyclothems to the south of the Wales-Brabant Massif (Poty et al., 2014; Poty, 2016), suggesting that where peritidal facies were deposited, they were preserved. The presence of short-lived exposure events truncating slightly deeper water platform interior facies on the Derbyshire Platform could be indicative of some allogenic forcing of relative sea level, but the discontinuity of the dominant Type A surfaces suggests emergence was short-lived and localised. It is also noteworthy that forward modelling of carbonate platform growth during icehouse periods indicates that the rapid rise in sea level during interglacials can lead to suppression of 
carbonate sedimentation and even platform drowning (Paterson et al., 2006; Masiero et al., 2020). There is no indication of such events in either of the platforms studied here or within age-equivalent strata south of the Wales-Brabant Massif (Poty et al., 2014) where facies above emergent surfaces are subtidal, and deposited in water depths around or above fair weather wave base. Furthermore, Paterson et al (2006) show that subsidence is a critical control on the morphology of carbonate platforms under the influence of glacio-eustacy, resulting in different sedimentary stacking patterns in areas of high subsidence - where there is more complete preservation of stratigraphy. In contrast, areas of lower subsidence can exhibit 'missed beats', formed by continued emergence of a platform top, even during sea level rise. The Holkerian was a tectonically quiescent period, between rift events, and movement along bounding faults that would have facilitiated footwall uplift and rotation (Fraser and Gawthorpe, 2003). It is possible, therefore, that the stacking patterns observed within the upper Asbian are in part driven by fault-controlled uplift . Furthermore, it can - tentatively - be implied that there are fewer emergent surfaces and greater preservation of strata on the Derbyshire Platform as a result of greater differential subsidence there compared to the North Wales Platform.

In summary, the data from this study and Manifold et al. (2020), suggests that evidence for systematic stacking and ordered parasequence development in the Asbian is less strong than has been previously invoked, calling into question the interpretation that the mid-Asbian marks the onset of fourth-order glacio-eustatically controlled cyclicity. Nevertheless, the increase in frequency of exposure surfaces, and decrease in bed thickness, up-section towards the Asbian - Brigantian boundary implies a decrease in accommodation space, consistent with a reduced rate of relative sea level rise across the basin. The Asbian - Brigantian boundary is a regionally correlatable karstic surface on both the Derbyshire and the North Wales Platforms, as well as in north Lancashire (Horbury, 1992) indicating that both platforms were exposed for some considerable time (Figure 11). It coincides with a number of important changes within the Pennine Basin, including a period of rifting and volcanism on the Derbyshire Platform (Fraser and Gawthorpe, 2003; Waters, 2009) and the influx of siliciclastic sediment in the northern Pennine Basin (so-called Yoredale Cycles; Tucker et al., 2009). It is also coincident with the diversification of Gigantoproductid brachiopods (Nolan et al., 2017). On the Namur-Dinant Platform carbonate sedimentation stopped during the Brigantian (Poty, 2016) whilst in the Rhenish Kulm Basin a sea level fall at the Asbian - Brigantian boundary is interpreted (Herbig, 2016). Therefore, although the hiatus could be indicative of significant, but still tectonically-controlled, basinal events, its recognition elsewhere in Europe, Russia as well as north America means that it could also be interpreted as a third - order sequence boundary associated with global cooling, as proposed by a number of previous studies (e.g. Smith and Read, 2000; Armendariz et al., Barnett et al., 2002; Giles, 2009; Qiao and Shen, 2015). Recent work suggests full icehouse conditions were not established until the very latest Mississippian (Serphukovian) or early Pennsylvanian (Montañez and Poulsen, 2013 and references therein), but the Asbian - Brigantian boundary perhaps provides the first indication of a critical change in global climate, associated with earliest stages of cooling, prior to the formation of peripolar ice formation in southern Gondwana (Montanez and Poulsen, 2013).

\section{CONCLUSIONS}

1) During the Asbian, healthy carbonate platform growth took place on the Derbyshire and North Wales platforms, with moderate- to high-energy conditions on the platform top sustained by a dominant northwesterly wind and currents driven through embayments and discontinuous facies belts on the platform margin.

2) Slope and platform margin stabilisation took place on windward (northern and western) margins by precipitation of radiaxial fibrous calcite cements, forming slope angles of 20 to $30^{\circ}$. These margins were subject to periodic, tectonically-induced margin and slope collapse, forming embayments. Margins which did not parallel active faults are more likely to be linear. Leeward margins dipped less steeply, with basinward transport of cohesive sediment by slumping and gravity flow.

3) Carbonate productivity was strongly controlled by a range of environmental factors, not just water depth, such that facies form a mosaic with laterally discontinuous exposure surfaces that cannot be correlated for more than a few hundred metres in outcrop. Micro- and macrofaunal ranges are long, such that in combination it is not possible to identify regionally extensive faunal bands or sedimentary surfaces that can be correlated within the Asbian succession across the region of study. 
4) On the Derbyshire Platform, syn-depositional volcanism produced extrusive lavas and volcanic ash deposits that are interbedded with Asbian limestone strata, but neither are seen on the North Wales Platform. On the North Wales Platform, periodic incursions of sandstone occur towards the top of the Asbian, sourced from landmasses to the south and west of the platform. Although fine grained siliciclastic mud incursions occurred on the palaeo-shoreline of the North Wales shoreline, it did not have a detrimental effect on carbonate productivity on the platform as whole.

5) Exposure events are less frequent, and surfaces less mature, on the Derbyshire Platform compared to the North Wales Platform, suggesting that sedimentation on the Derbyshire Platform occurred on deeper water and therefore had fewer, shorter exposure events. The succession of calcretes, palaeosols, mammilated surfaces, and rare coals, on the North Wales Platform indicate climate fluctuations between semi-arid and semihumid conditions. These more frequent periods of platform exposure do not seem to have decreased the keep-up capacity of the platform because shallow-water platform top Asbian strata on both platforms are approximately $200 \mathrm{~m}$ thick.

6) In the latest Asbian, a sustained period of platform exposure created a regionally correlatable, relatively deepcutting mamillated surface. A marked change in facies occurs above this surface, which is also present to the north of the study area, marked by the onset of the Yoredale depositional system. This suggests that it is the most reliable datum for correlation across the Pennine Basin

7) As well as having regional significance, the Asbian - Brigantian boundary could have greater global significance than has been acknowledged in recent years, potentially marking the onset of global cooling that had a marked environmental effect on subsequent carbonate platform growth. Given the lack of evidence for ordering and cyclicity within Asbian strata on the Derbyshire and North Wales Platform, it is proposed that the Asbian Brigantian boundary is a stronger indicator the climatic transition associated with the second glacial advance of the Late Palaeozoic Ice Age, and potentially the onset of fourth-order glacio-eustacy.

\section{ACKNOWLEDGEMENTS}

The authors would like to thank Tullow Oil (Ireland), Wintershall DEA (Germany) and Woodside Energy (Australia), who funded this project via the PD3 Consortium. Thanks go to Jim Hendry, Frauke Schulze, Mary Monroe, Fiona Whitaker, Atle Rotevatn, Kenneth McCormack, Isabella Masiero, Irina Korneva and Peter Gutteridge for their useful discussions and input that helped develop the concepts and interpretations. The detailed comments of Markus Aretz and an anonymous reviewer, and editorial support from Stephen Lokier, substantially improved an earlier version of this manuscript.

\section{REFERENCES}

Aitkenhead, N., Chisholm, J.I. and Stevenson, I.P. (1985). Geology of the Country around Buxton, Leek and Bakewell. Memoir of the British Geological Survey, Sheet 111.

Armendariz, M., Rosales, I and Qesada, C, 2008 Oxygen isotope and Mg/Ca composition of Late Viséan (Mississippian) brachiopod shels from SW Iberia: Palaeoclimateic and palaeogeographic implications in northern Gondwana. Palaeogeography, Palaeoclimatology and Palaeoecology, 268, 65-79

Arnold-Bemrose, H.H. (1907). The Toadstones of Derbyshire: their Field-Relations and Petrography. Journal of the Geological Society, 63, 241-248.

Aretz, M and Herbig, H-G (2003) Coral-rich bioconstructions in the Viséan (Late Mississippian of Southern Wales (Gower Peninsula, UK). Facies, 49, 221-242

Aretz, M. and Chevalier, E (2007) After the collapse of stromatoporoid - coral reefs - the Fammenian and Dinantian reefs of Belgium: much more than Waulsortian mounds. In: Palaeozoic Reefs and Bioconstructions: Climatic and evolutionary Controls (Ed. J. Alvaro, M. Aretz, F. Boulvain, A., Munnecke, D. Vachard and E. Vennin). Geological Society Special Publication, 275, 163-188 
Bahamonde, J. R., Kenter, J.A.M., Della Porta, G., Keim, L., Immenhauser, A. and Reijmer, J.J.G. (2004). Lithofacies and depositional processes on a high, steep-margined Carboniferous (Bashkirian-Moscovian) carbonate platform slope, Sierra del Cuera, NW Spain. Sedimentary Geology, 166, 145-156.

Bancroft, A.J., Somerville, I.D., and Strank, A.R.E. (1988). A bryozoan buildup from the Lower Carboniferous of North Wales. Lethaia, 21, 51-65.

Barham, M., Murray, J., Joachimski, M.M. and Williams, D.M. (2012). The onset of the Permo-Carboniferous glaciation: reconciling global stratigraphic evidence with biogenic apatite $\delta 18 \mathrm{O}$ records in the late Viséan. Journal of the Geological Society, 169(2), 119-122.

Barnett, A.J., Burgess, P.M. and Wright, V.P. (2002). Icehouse world sea-level behaviour and resulting stratal patterns in late Viséan (Mississippian) carbonate platforms: integration of numerical forward modelling and outcrop studies. Basin Research, 14, 417-438.

Bathurst, R.G.C. (1959). The cavernous structure of some Mississippian Stromatactis reefs in Lancashire, England. Journal of Geology, 67, pp. 506-521.

Billing, I.M (1991). British Carboniferous Bryozoan Biogeography. Unpublished PhD Thesis, Durham University.

Brand, U. (1989). Biogochemistry of late Palaeozoic North American Brachiopods and Secular Variation of Seawater Composition. Biogeochemistry, 7(3), 159-193.

Bridge, D. McC., and Gozzard, J.R. (1981). The limestones and dolomite resources of the country around Monyash, Derbyshire. Institute of Geological Sciences, Mineral Assessment Report, 138.

Broadhurst, F. M., and Simpson, I.M. (1973). Bathymetry on a Carboniferous reef. Lethaia, 6, 367-381.

Broadhurst, F.M. and Simpson, I.M. (1967). Sedimentary infillings of fossils and cavities in limestone at Treak Cliff, Derbyshire. Geological Magazine, 104, 443-448.

Buggisch, W., Joachimski, M., Sevastopulo, G. and Morrow, J (2008). Mississippean $\delta^{13} \mathrm{C}$ and conodont apatite $\delta^{18} \mathrm{O}$ records - their relation to the Late Palaeozoic Glaciation. Palaeogeography, Palaeoclimatology, Palaeoecology, 268, 273-292

Burgess, P.M. (2016). Identifying ordered strata: evidence, methods, and meaning. Journal of Sedimentary Research, 86, $148-167$.

Burgess, P.M. and Pollitt, D.A. (2012). The origins of shallow-water carbonate lithofacies thickness distributions: one dimensional forward modelling of relative sea-level and production rate control. Sedimentology, 59, 57-80.

Chadwick, R.A., Holliday, D.W., Holloway, S. and Hulbert, A.G. (1995). Structure and evolution of the Northumberland-Solway Basin and adjacent areas. London, British Geological Survey Subsurface Memoir, Her Majesty's Stationary Office, 90.

Cocks, L.R.M and Torsvik,T.H (2011) The Palaeozoic geography of Laurentia and western Laurussia: A stable craton with mobile margins. Earth-Science Reviews, 106, 1-51

Conil R, Groessens E, Laloux M, Poty E, Tournier F. (1991). Carboniferous guide foraminifera, corals and conodonts in the Franco-Belgian and Campine Basins: their potential for widespread correlation. Courier Forschungsinstitut Senckenberg 130, 15-30.

Conil, R., Longerstaey, P.J., and Ramsbottom, W.H.C. (1979). Materiaux pour I'etude micropaleontolgique du Dinantian de Grande-Bretagne. Memoire Institue Geologie, Louvain, 30, 1-187.

Copper, P. (1988). Ecological succession in Phanerozoic reef ecosystems: is it real? Palaios, 3, 136-151.

Coward, M.P. (1993). The effect of Late Caledonian and Variscan continental escape tectonics on basement structure, Paleozoic basin kinematics and subsequent Mesozoic basin development in NW Europe. J.R. Parker. (ed.). Petroleum Group of Northwest Europe: Proceedings of the $4^{\text {th }}$ Conference, 1095-1108.

Cox F.C. and Bridge, D. McC. (1977). The limestones and dolomite resources of the country around Wirksworth, Derbyshire. Institute of Geological Sciences, Mineral Assessment Report, 139.

Cox F.C. and Harrison, D.J. (1980). The limestones and dolomite resources of the country around Wirksworth, Derbyshire. Institute of Geological Sciences, Mineral Assessment Report, 139.

Davies, J.R., Riley, N.J. and Wilson, D. (1989). The distribution of Chadian and earliest Arundian strata in North Wales: implications for Dinantian (Carboniferous) lithostratigraphy and palaeogeography. Geological Journal, 24, 3147. 
Davies, J.R., Wilson, D. and Williamson, I.T. (2004). Geology of the Country Around Flint. Memoir of the British Geological Survey, Sheet 108.

De Silva, S. and Lindsay, J.M. (2015). Primary Volcanic Landforms. In: Sigurdsson, H., Houghton, B., McNutt, S., Rymer, H. and Stix, J. The Encyclopedia of Volcanoes, $2^{\text {nd }}$ Edition. Academic Press.

Della Porta, G. (2003). Depositional anatomy of a Carboniferous high-rising carbonate platform (Cantabrian Mountains, NW Spain). Unpublished PhD thesis, Vrije Universiteit, Amsterdam.

Dickson, J.A.D. (1965). A Modified Staining Technique for Carbonates in Thin Section. Nature, 205, 597.

Dunham, R.J. (1962). Classification of carbonate rocks according to depositional texture. AAPG Memoir, 1, 108-121.

Durand, N., Monger, C., and Canti, N.G. (2010). Calcium Carbonate Features. In: Interpretation of Micromorphological Features of Soils and Regoliths. Elsevier. B.V.

Ebdon, C.C., Fraser, A.J., Higgins, A.C., Mitchener, B.C. and Strank, A.R.E. (1990). The Dinantian stratigraphy of the East Midlands: a seismostratigraphic approach. Journal of the Geological Society, London, 147, 519-536.

Falcon-Lang, H.J. (1999a). The Early Carboniferous (Courceyan-Arundian) monsoonal climate of the British Isles: evidence from growth rings in fossil woods. Geological Magazine, 136, 177-187.

Falcon-Lang, H.J. (1999b). The Early Carboniferous (Asbian-Brigantian) seasonal tropical climate of northern Britain. Palaois, 14, 116-126.

Fedorowski, J. (2008). Early Carboniferous Chinese and Australian "Siphonodendron" (Anthozoa, Rugosa): ecological and geographical influence on taxonomy. Geologos, 14(1), 3-17.

Floodpage, J., Newman, P and White, J., 2001. Hydrocarbon prospectivity in the Irish Sea area: insights from recent exploration of the Central Irish Sea, Peel and Solway Basins. In: The Petroleum Exploration of Ireland's Offshore Basins (Ed. P. Shannon, P. Haughton and D. Corcoran), Geological Society London Special Publications, 188, 107-134.

Ford, T.D. (1987). The origin of the Winnats Pass, Castleton, Derbyshire. Mercian Geologist, 10, 241-249.

Fraser, A.J., and Gawthorpe, R.L. (1990). Tectono-stratigraphic development and hydrocarbon habitat of the Carboniferous in northern England. In: Hardman, R.F.P. and Brooks, J. (eds.). Tectonics Events Responsible for Britain's Oil and Gas Reserves. Geological Society Special Publication, 55, 49-56.

Fraser, A.J. and Gawthorpe. R.L. (2003). An Atlas of Carboniferous Basin Evolution in Northern England: Geological Society of London Memoir, 28, 70.

Fraser, A.J., Nash, D.F., Steele, R.P. and Ebdon, C.C. (1990). A regional assessment of the Intra-Carboniferous play of northern England: Special Publication of the Geological Society of London.

Frazer, M., Whitaker, F. and Hollis, C. (2014). Fluid expulsion from overpressured basins: Implications for Pb-Zn mineralisation and dolomitisation of the East Midlands platform, northern England. Marine and Petroleum Geology, 55, 68-86.

Gallagher, S.J. (1998). Controls on the distribution of calcareous Foraminifera in the Lower Carboniferous of Ireland. Marine micropaleontology, 34(3-4), 187-211.

Gallagher, S.J. and Somerville, I.D. (2003). Lower Carboniferous (Late Viséan) platform development and cyclicity in southern Ireland: Foraminiferal biofacies and lithofacies evidence. Rivista Italiana di Paleontologia e Stratigrafia (Research In Paleontology and Stratigraphy), 109(2).

Garwood, E.J. (1913). The Lower Carboniferous succession in the northwest of England. Quarterly Journal of the Geological Society, London, 68, 449-596.

Gawthorpe, R. L. and Gutteridge, P. (1990). Geometry and evolution of platform-margin bioclastic shoals, late Dinantian (Mississippian), Derbyshire, UK. Special Publication of the International Association of Sedimentologists, 9, 39-54.

Gingras, M.K., Macmillan, B., Balcom, B.J., Saunders, T. and Pemberton, S.G. (2002). Using magnetic resonance imaging and petrographic techniques to understand the textural attributes and porosity distribution in Macaronichnus-burrowed sandstone. Journal of Sedimentary Research, 72, 552-558.

Godderis, Y., Donnadieu, Y., Carretier, S., Aretz, M., Dera, G., Macouin, M and Regard, V. (2017). Onset and ending of the late Palaeozoic ice age triggered by tectonically paced rock weathering. Nature Geoscience, 10, 382-386

Gong, E., Zhang, Y., Guan, C., Chen, X. (2012). The Carboniferous reefs in China. Biopalaeogeography and palaeoecology, 1, 27-42. 
Gutteridge, P. (1987). Dinantian sedimentation and basement structure of the Derbyshire Dome. Geological Journal, 22, 25-41.

Gutteridge, P. (1990). The origin and significance of the distribution of shelly macrofauna in late Dinantian carbonate mud mounds of Derbyshire. Proceedings of the Yorkshire Geological Society, 48(1), 23-32.

Gutteridge, P. (1991). Aspects of Dinantian sedimentation in the Edale Basin, North Derbyshire. Geological Journal, 26, 245-269.

Gutteridge, P. (1995) Late Dinantian (Brigantian) carbonate mud-mounds of the Derbyshire carbonate platform. Special Publication International Association of Sedimentologists, 23, 289-307.

Haldar, S.K. and Tišljar, J. (2014) Igneous Rocks. In: Introduction to Mineralogy and Petrology, 92-120.

Haq, B.U. and Schutter, S.R. (2008). A Chronology of Paleozoic Sea-Level Changes. Science, 322, 64-68.

Harrison, D.J. (1981). The limestones and dolomite resources of the country around Buxton, Derbyshire. Institute of Geological Sciences, Mineral Assessment Report, 108.

Harwood, M. (2005). The Facies Architecture and Depositional Geometry of a Late Viséan Carbonate Platform Margin, Derbyshire, UK. Unpublished PhD Thesis, University of Cardiff, UK.

Heckel, P.H. (1974). Carbonate buildups in the geological record: a review. SEPM Special Publication Reefs in Time and Space, 18, 90-155.

Heckel, P.H. (1990). Evidence for global (glacial-eustatic) control over upper Carboniferous (Pennsylvanian) cyclothems in midcontinent North America. Geological Society of London Special Publication, 55, 35-47.

Herbig, H-G (2016) Mississippian (Early Carboniferous) sequence stratigraphy of the Rhenish Kulm Basin, Germany. Geological Belgica, 19/1-2, 81-110

Horbury, A.D. (1992). A Late Dinantian peloid cementstone-palaeoberesellid buildup from North Lancashire, England. Sedimentary Geology, 79, 117-137.

Horbury, A.D. and Adams, A (1989). Meteoric phreatic diagenesis in cyclic late Dinantian carbonates, northwest England. Sedimentary Geology, 65, 319-344

Howells, M.F., 2007. British Regional Geology: Wales. British Geological Survey, Keyworth.

James, N.P. (1983). Reef Environment. In: Scholle, P.A., Bebout, D.G. and Moore, C.H. (eds.) Carbonate Depositional Environments. AAPG Memoir, 33, 345-440.

Jones, R.W. (2006). Applied Palaeontology. Cambridge University Press, 42 pp.

Juerges, A., Hollis, C.E., Marshall, J. and Crowley, S. (2015). The control of basin evolution on patterns of sedimentation and diagenesis: an example from the Mississippian Great Orme, North Wales. Journal of the Geological Society, 173, 438-456.

Kendall, A.C. (1985). Radiaxial fibrous calcite: a reappraisal. In: Schneidermann, N. and Harris, P.M. (eds.) Carbonate Cements. SEPM Special Publication, 36, 59-77.

Kenter, J. A. M. (1990). Carbonate platform flanks: slope angle and sediment fabric. Sedimentology, 37, 777-794.

Kirkby, M. J. (1987). General models of long-term slope evolution through mass-movement. Chichester: Wiley.

Klappa, C.F., 1980. Rhizoliths in terrestrial carbonates: classification, recognition, genesis and significance. Sedimentology, 27, 613-619.

Lakin, J.A., Marshall, E.A., Troth, I and Harding, I.C. (2016) Greenhouse to icehouse: a biostratigraphic review of the latest Devonian - Mississsippian glaciations and their global effect. In: Devonian Climate, Sea Level and Evolution Events, Geological Society London Special Publications, 423, 439-464

Liu, J., Algeo, T., Wenkun, Q and Saltzman, M. (2019) Intensified oceanic circulation during Early Carboniferous cooling events: Evidence from carbon and nitrogen isotopes. Palaeogeography, Palaeoclimatology, Palaeoecology, 531

Manifold, L. (2019). Characterising the sedimentological heterogeneity of Mississippian carbonate platforms of England and Wales. Unpublished PhD Thesis, University of Manchester, UK.

Manifold, L. (2020). The Anatomy of a Mississippian (Viséan) carbonate platform interior, UK: Depositional cycles, glacioeustasy and facies mosaics. Sedimentary Geology, 401, 1-14.

Maroof, S.I. (1976). The structure of the concealed pre-Carboniferous basement of the Derbyshire Dome from gravity data, Proceedings of the Yorkshire Geological Society, 41, 59-69. 
Masiero, I. (2020). Investigating the Structural Control Over Syn-Rift Carbonate Platforms Using Statigraphic and Seismic Forward Models. Unpublished PhD Thesis, University of Liverpool, UK.

Mii, H-S., Grossman, E and Yancey, T., 1999. Carboniferous isotope stratigraphies of North America: Implications for Carboniferous palaeoceanography and Mississippian glaciation. GSA Bulletin, 111, 960-973

Miller, J., and Grayson, R.F. (1982). The regional context of Waulsortian facies in N. England. In: Bolton, K., Lane, H.R., and LeMonda, D.V. (eds.) Symposium on the Palaeoenvironmental Setting and Distribution of Waulsortian Facies, El Paso, El Paso Geological Society, 17-33.

Montañez, I and Poulson, C. (2013) The Late Palaeozoic Ice Age: An Evolving Paradigm. Annual Rev. Earth. Planet. Sci., 41, 629-656

Neaverson, E. (1930). The Carboniferous rocks around Prestatyn, Dyserth and Newmarket (Flintshire), Historical Review. Proceedings of the Liverpool Geological Society, 15, 179-212.

Neaverson, E. (1937). The Carboniferous rocks between Llandudno and Colwyn Bay, North Wales. Proceedings of the Liverpool Geological Society, 17, 115-135.

Nichols, R. A. H. (1965). Petrology of a Lower Carboniferous bryozoan limestone and adjacent limestones in North Wales, Great Britain. Journal of Sedimentary Petrology, 35, 887-899.

Nichols, R.A.H. (1961). Comparative studies of the Carboniferous limestones of Anglesey and the mainland of North Wales. Unpublished PhD thesis, University College of Wales, Aberystwyth.

Nolan, L., Angiolini, L., Jadoul, F., Dell Porta, G., Davies, S., Stephenson, M and Leng, M., 2017. Sedimentary context and palaeoecology of Gigantoproductus shell beds in the Mississippian Eyam Limestone Formation, Derbyshire carbonate platform, central England. Proceedings of the Yorkshire Geological Society, 61, 329-257

Oehlert, A., Swart, P., Eberli, G., Evans, S and Frank, T., 2019. Multi-proxy constraints on the significance of covariant $\delta^{13} \mathrm{C}$ values in carbonate and organic carbon during the early Mississippian. Sedimentology, 66, 241-261

Paterson, R., Whitaker, F., Jones, G., Smart, P., Waltham, D. and Felce, G., 2006. Accomodation and sedimentary architecture of isolated icehouse carbonate platforms from forward modelling with Carb3 ${ }^{+}$. Journal of Sedimentary Research, 76, 1162-1182

Pickard, N.A.H. (1996). Evidence for microbial influence on the development of Lower Carboniferous (Dinantian) buildups. Geological Society of London, Special Publication, 107.

Piper, J.D.A., Atkinson, D., Norris, S. and Thomas., S. (1991). Palaeomagnetic study of the Derbyshire lavas and intrusions, central England: definition of Carboniferous apparent polar wander. Physics of the Earth and Planetary Interiors, 69(1-2), 37-55.

Pharaoh, T., Gent, C., Hannis, S., Kirk, K, Monahan, A., Quinn, M., Smith, N., Vane, C., Wakefield, O and Waters, C., (2018). An overlooked play? Structure, stratigraphy and hydrocarbon prospectivity of the Carboniferous in the East Irish Sea - North Channel basin complex. In: Palaeozoic Plays of North West Europe. Geological Society of London Special Publication, 471

Poty, E., Artetz, M and Hance, L (2014). Belgian substages as a basis for an international chronostratigraphic division of the Tournasian and Viséan. Geological Magazine, 151, 229-243

Poty, E. (2016) The Dinantian (Mississippian) succession of southern Belgium and surrounding areas: stratigraphy improvement and inferred climate reconstruction. Geologica Belgica, 19/1-2, 177-200

Qiao, L and Shen, S-A., 2015. A global review of the Late Mississippian (Carboniferous) Geigantoproductus (Brachioopoda) faunas and their palaeogeographical, palaeoecological and palaeoclimatic implications. Paleogeography, Palaeoclimatology, Palaeoecology, 420, 128-137

Ramsay, A. C. (1886). The geology of North Wales. In: Geological Survey Great Britain: Second Edition, Memoir of the Geological Survey of the UK, 3.

Rankey, E.C. and Reeder, S.L. (2012). Tidal Sands of the Bahamian Archipegalo. In: Davis, R.A. Jr. and Dalrymple, R.W. (eds.) Principles of Tidal Sedimentology. Springer Science+Business Media B.V.

Rankey, E.C., Riegel, B. and Steffen, K. (2006). Form, function and feedbacks in a tidally dominated ooid shoal, Bahamas. Sedimentology, 53(6), 1191-1210.

Rohde, R. (2005). Asbian/Brigantian Regional Stage. Geowhen Database: http://www.stratigraphy.org/bak/geowhen/stages/Asbian.html. Date accessed: 16/11/2018. 
Rosa, E.L.M., Vesely, F.F., Isbell., J.L., Kipper, F., Fedorchuk, N.D., Souza, P.S. (2019). Constraining the timing, kinematics and cyclicity of Mississippian-Early Pennsylvanian glaciations in the Paraná Basin, Brazil. Sedimentary Geology, 384, 29-49.

Ryland, J.S. (1970). Bryozoans. The analysis of spatial distribution patterns. In: Larwood, G.P. (ed.). Living and Fossil Bryozoa, 165-172. Academic Press, London, 634.

Sandberg, P. A. (1983) An oscillating trend in Phanerozoic nonskeletal carbonate mineralogy. Nature, 305, 19-22

Sevastopulo, G. and Barham, M. (2014), Correlation of the base of the Serphukhovian Stage (Mississsippian) in NW Europe. Geol. Mag., 151, 244-253

Schlager, W. and Ginsburg, R.N. (1981) Bahama carbonate platforms - The deep and the past. Marine Geology, 44(1-2), 1-24.

Schofield, K. (1982). Sedimentology of the Woo Dale Limestone Formation, Derbyshire. Unpublished PhD thesis, University of Manchester.

Schofield, K. and Adams, E. (1985). Stratigraphy and depositional environments of the Woo Dale Formation. Proceedings of the Yorkshire Geological Society, 245, 225-233.

Shen, J-W. and Webb, G.E. 2008. The role of microbes in reef-building communities of the Cannindah limestone (Mississippian), Monto region, Queensland, Australia. Facies, 54, 89-105.

Shirley, J., and Horsfield, E.L. (1940). The Carboniferous Limestone of the Castleton - Bradwell area, North Derbyshire. Quarterly Journal of the Geological Society of London, 96, 271-299.

Simpson, I. M., and Broadhurst, F.M. (1969). A boulder bed at Treak Cliff, North Derbyshire. Proceedings of the Yorkshire Geological Society, 37, part 2(6), 141-151.

Slavin, G., and Slavin, B. (2005). The apron reef above Castleton. Mercian Geologist, 16(2), 142-143.

Smith, K., Smith, N.J.P. and Holliday, D.W. (1985). The Deep Structure of Derbyshire. Geological Journal, 20, $215-225$.

Smith, L. B., and Read, J.F. (2000). Rapid onset of Late Paleozoic glaciation: evidence from Upper Mississippian strata of the Midcontinent, United States. Geology, 28, 279-282.

Smith, L.B. and Read, J.F. (1999). Application of high-resolution sequence stratigraphy to tidally influenced Upper Mississippian carbonates, Illinois basin. In: Harris, P.M., Saller, A.H., and Simo, J.A. (eds.). Advances in Carbonate Sequence Stratigraphy: Application to Reservoirs, Outcrops and Models. SEPM Special Publication, 63, 107-126.

Somerville, I.D. (1979). A cyclicity in the early Brigantian (D2) limestones east of the Clwydian Range, North Wales and its use in correlation. Proceedings of the Yorkshire Geological Society, 42, 397-404.

Somerville, I.D. (2003). Review of Irish Lower Carboniferous (Mississippian) Mud Mounds: depositional setting, biota, facies and evolution. SEPM Special Publication No. 78 and AAPG Memoir 83.

Somerville, I.D. (2008). Biostratigraphic zonation and correlation of Mississippian rocks in Western Europe: some case studies in the late Viséan/Serpukhovian. Geological Journal, 43(2-3), 209-240.

Stevenson, I. P., and Gaunt, G.D. (1971). The Geology of the Country around Chapel en le Frith. Memoir of the Geological Survey of Great Britain, sheet 99, 444.

Strank, A.R.E. (1981). Foraminiferal biostratigraphy of the Holkerian, Asbian and Brigantian stages of the British Lower Carboniferous. Unpublished PhD Thesis, University of Manchester.

Trewin, N.H. (1968). Potassium bentonites in the Namurian of Staffordshire and Derbyshire. Proceedings of the Yorkshire Geological Society, 37(1), 73-91.

Trewin, N.H. and Holdsworth, B.K. (1972). Sedimentation in the Lower Namurian Rocks of the North Staffordshire Basin. Proceedings of the Yorkshire Geological Society, 39(3), 371-408.

Tucker, M.E., Gallagher, J. and Leng, M.J. (2009). Are beds in shelf carbonates millennial-scale cycles? An example from the mid-Carboniferous of northern England.... Sedimentary Geology, 214, 19-34.

van der Kooij, B., Immenhauser, A., Steuber, T., Bahamonde, J.R. and Merino Tomé, O. (2010). Precipitation mechanisms of volumetrically important early marine carbonate cement volumes in deep slope settings. Sedimentology, 57, 1491-1525.

Van Wagoner, J.C., Mitchum, R.M., Campion, K.M., Rahmanian, D. (1990). Siliciclastic Sequence Stratigraphy in Well Logs, Cores, and Outcrops: Concepts for High-Resolution Correlation of Time and Facies. American Association of Petroleum Geologists, 7. 
Vanstone, S. (1996). The influence of climatic change on exposure surface development: a case study from the Late Dinantian of England and Wales. Geological Society Special Publication, 107.

Vanstone, S. (1998). Late Dinantian palaeokarst of England and Wales: Implications for exposure surface development. Sedimentology, 45 (1).

Vaughan, A. (1905). The palaeontological sequence in the Carboniferous Limestone of the Bristol Area. Quarterly Journal of the Geological Society, London, 61, 181-307.

Walkden, G. M., and Davies, J. (1983). Polyphase erosion of subaerial omission surfaces in the late Dinantian of Anglesey, North Wales. Sedimentology, 31, 251-267.

Walkden, G. M., and Davies, J. (1983). Polyphase erosion of subaerial omission surfaces in the late Dinantian of Anglesey, North Wales. Sedimentology, 31, 251-267.

Walkden, G.M and Williams, D.O. (1991). The diagenesis of the late Dinantian Derbyshire-East Midlands carbonate shelf, central England. Sedimentology, 38, 643-670.

Walkden, G.M. (1972) The mineralogy and origin of interbedded clay wayboards in the Lower Carboniferous of the Derbyshire Dome. Geological Journal, 8, 143-159.

Walkden, G.M., (1974), Palaeokarstic Surfaces in Upper Viséan (Carboniferous) Limestone of the Derbyshire Block, England, Journal of Sedimentary Petrology, 44, 1232-1247.

Waters, C., Waters, R.A., Barclay, W.J. and Davies, J.R (2009) A lithostratigraphical framework for the Carboniferous successions of southern Great Britain (onshore). British Geological Survey Research Report RR/09/01

Wolverson Cope, F. (1936). Some features in the D1-D2 limestones of the Miller's Dale region, Derbyshire. Proceedings of the Yorkshire Geological Society, 23, 178-195.

Wolverson Cope, F. (1938). The Mid-Viséan (S2-D1) succession in North Derbyshire and North-West England. Proceedings of the Yorkshire Geological Society, 24, 60-66.

Wright, V. P. and Burgess, P. M. (2005). The carbonate factory continuum, facies mosaics and microfacies: an appraisal of some of the key concepts underpinning carbonate sedimentology. Facies, 51, 17-23.

Wright, V.P. (1980). Climatic fluctuations in the Lower Carboniferous. Naturwissenschaften, 67, 252-253.

Wright, V.P. (1982). Calcrete Palaeosols from the Lower Carboniferous Llanelly Formation, South Wales. Sedimentary Geology, 33, 1-33.

Wright, V.P. (1986). Facies sequences on a carbonate ramp: the Carboniferous Limestone of South Wales. Sedimentology, 33, 221-241.

Wright, V.P. (1992) Speculation on the controls on cyclic peritidal carbonates: ice-house versus greenhouse eustatic controls. Sedimentary geology, 76(1-2), 1-5.

Wright, V.P. and Vanstone, D. (2001). Onset of Late Palaeozoic glacio-eustacy and the evolving climates of low latitude areas: a synthesis of current understanding. Journal of the Geological Society, London, 15, 579-582. 
Figure Captions

Figure 1: Palaeogeography map of the mid-Asbian modified from Floodpage et al. (2001) and Fraser and Gawthorpe (2003) with outcrops and field areas highlighted.

Figure 2: Seismostratigraphic divisions of the Pennine Basin, after Ebdon et al. (1990), Fraser (1990), Fraser and Gawthorpe (2003), extrapolated to the North Wales Platform, $130 \mathrm{~km}$ westwards, with major tectonic and climatic events.

Figure 3: Map of the UK, with faults in Carboniferous strata highlighted, indicating two main field areas, A) The Great Orme, North Wales (BGS 1:10,000, 2016), B) Derbyshire (Fraser and Gawthorpe, 2003; Frazer et al. 2014).

Figure 4: A: Platform characteristics of the lower-mid Asbian northern margin of the North Wales Platform, showing a band of shallow-water skeletal mudstone-wackestone. The remainder of the platform is inferred to be emerged. B: Platform characteristics of the mid-upper Asbian southern margin of the Derbyshire Platform, showing a relatively shallow slope with slumping at the margin, and small mounds, minor grainstones and laterally discontinuous exposure events in the interior. C: Platform characteristics of the mid-upper Asbian northern margin of the Derbyshire Platform, showing a mound and shoal complex at the margin above a steep slope with boulder beds. Within the platform interior, minor grainstones, volcanics, and laterally discontinuous exposure events are characteristic. D: Platform characteristics of the mid-upper Asbian northern margin of the North Wales Platform. The margin is not exposed, but near the margin, shoals and mounds outcrop and there is one example of microbial mats. Landwards, siliciclastic mudstones and coals, occur in the interior around the Asbian - Brigantian boundary.

Figure 5: (A) Steeply dipping northern margin of the Derbyshire Platform cemented debrites. (B) The fabric of debrites is best observed on a polished surface. They comprise fragmented, centimetre-scale bioclasts which are cemented by white radiaxial-fibrous cements. The southern margin of the Derbyshire Platform comprises slumped, dolomitized floatstones (C and D), Harborough Rocks.

Figure 6: Summary of principal distinctive microfacies identified, referred to throughout text. PPL = Plane polarised light; XPL = cross polarised light. A: (PPL) Platform slope facies (Winnats Pass, Locality 18) comprising cloudy, radiaxially cemented brachiopods which are partly dissolved; B: (PPL) Diverse algal assemblage hosted by clear cements sampled from the western margin of the Derbyshire Platform (Locality K); C: (PPL) Sample of mound from the North Wales Platform (Little Orme, Locality 20) comprising fenestrate bryozoans hosted by sucrosic sparite. The right hand side of the section is dolomitised; D: (XPL) Second sample from mound from the North Wales Platform (Little Orme, Locality 20) comprising radiaxially cemented Koninckopora (dasycladacean algae); E: (PPL) Typical example of platform interior facies comprising micritehosted packstone with highly fragmented bioclasts (Great Orme, Locality D); F: (PPL) Carbonate mud-wackestone from an emergent surface (Great Orme, Locality D), partially dissolved and replaced by cement.

Figure 7: A: lateral log of the carbonate mound of the Little Orme, North Wales Platform; B: lateral $\log$ of the carbonate mound of Pin Dale Quarry, Derbyshire Platform; C: vertical log of the carbonate mound of Pin Dale Quarry, Derbyshire Platform. Note the different scales of each log. 
Figure 8: A: thickly bedded platform interior bioclastic wackestones and packstones with bioturbated beds, North Wales Platform; B: location of coral-dominated mound, morphology of mound, and densely packed Siphonodendron corals, northern platform interior, North Wales Platform; C: form lines of skeletal and algal grainstones, parallel to the margin, North Wales Platform. D: stratiform and pinnacle laminites, northern margin, North Wales Platform.

Figure 9: Photogmicrographs of: A: Koninckopora inflata (Loggerheads Limestone), B: Bibradya sp. (Monsal Dale Limestone), C: Omphalotis omphalota (Loggerheads Limestone), D: Forschia sp. (Loggerheads Limestone), E: Cribrospira panderi (Bee Low Limestone), F: Cribrostomum sp. (Loggerheads Limestone), G: Lituotubella glomospiroides (Loggerheads Limestone), H: Eostaffella

Figure 10A: Exposure-related facies.

i: Type A, undulating limestone, North Wales Platform;

ii: Type B, nodular limestone, north wales Platform;

iii: red-coloured unconsolidated muds and clays, North Wales Platform;

iv: brown-coloured unconsolidated muds and clays with plant material and quartz clasts, Derbyshire Platform; v: yellow-coloured unconsolidated muds and clays, North Wales Platform.

Figure 10B: Igneous facies in core.

i: contact between extrusive volcanics (weathered basalt) and Bee Low limestone, Derbyshire Platform;

ii: multicoloured volcanic ash from core, Derbyshire Platform.

Figure 10C:

i: Mudrock overling and draping a Type A mammilated surface, Trefor Rocks, North Wales Platform

ii: Mudrock bed between two limestone beds, with no evidence of emergence, suggesting marine deposition, Trefor Rocks, North Wales Platform

iii: Dark green palaeosol overlying karstic surface beneath Asbian - Brigantian boundary, Tarmac

Hendre Quarry, near Mold. Green-brown weathered limestone is Asbian, grey-weathered limestone is Brigantian

Figure 11: Regional exposure surface cropping out on the North Wales Platform (top photo; Locality G) and Derbyshire Platform (bottom photo) where it is characterised by a $0.5 \mathrm{~m}$ thick package of rubbled limestone and unconsolidated mud/clay (Redhill Quarry, $4 \mathrm{~km}$ north of Locality 17).

Figure 12: Volcanic centres near Buxton (NW) and Matlock (SE) and the approximate distribution of volcanic ash based on core observations by Cox and Bridge (1977), Cox and Harrison (1980), Bridge and Gozzard, (1981) and Harrison (1981).

Figure 13: Biostratigraphic correlation across the Derbyshire and North Wales Platfroms (west to east), with Asbian - Brigantian boundary highlighted. 
Figure 14: Regional Asbian palaeogeography, modified from Floodpage et al. (2001) andFraser and Gawthorpe (2003). A: ramp development on the Derbyshire Platform with initial stages of margin formation on both platforms. B: development of flat-topped platforms in Derbyshire and North Wales, C: Regional platform emergence and siliciclastic inundation on the North Wales Platform. 


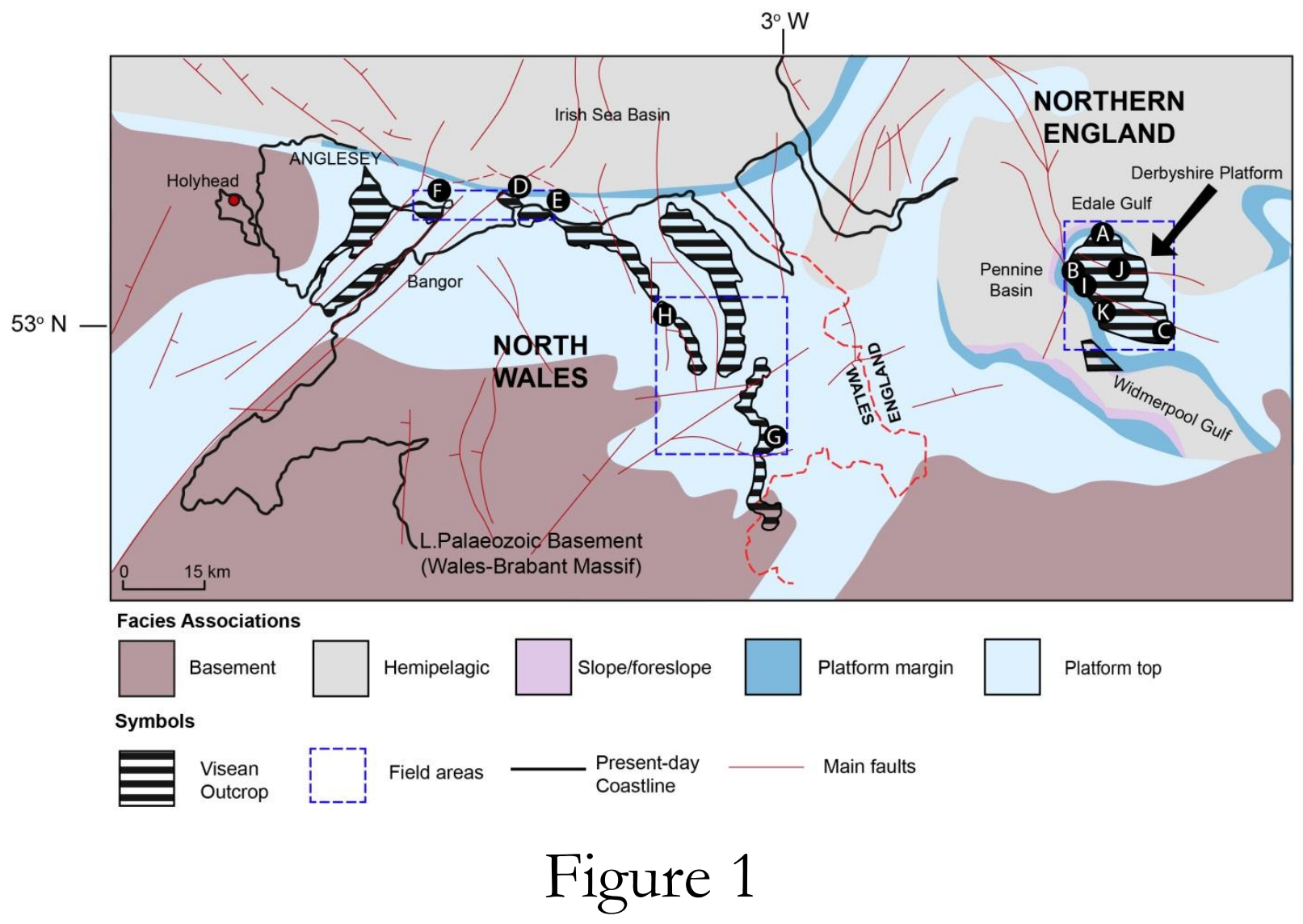




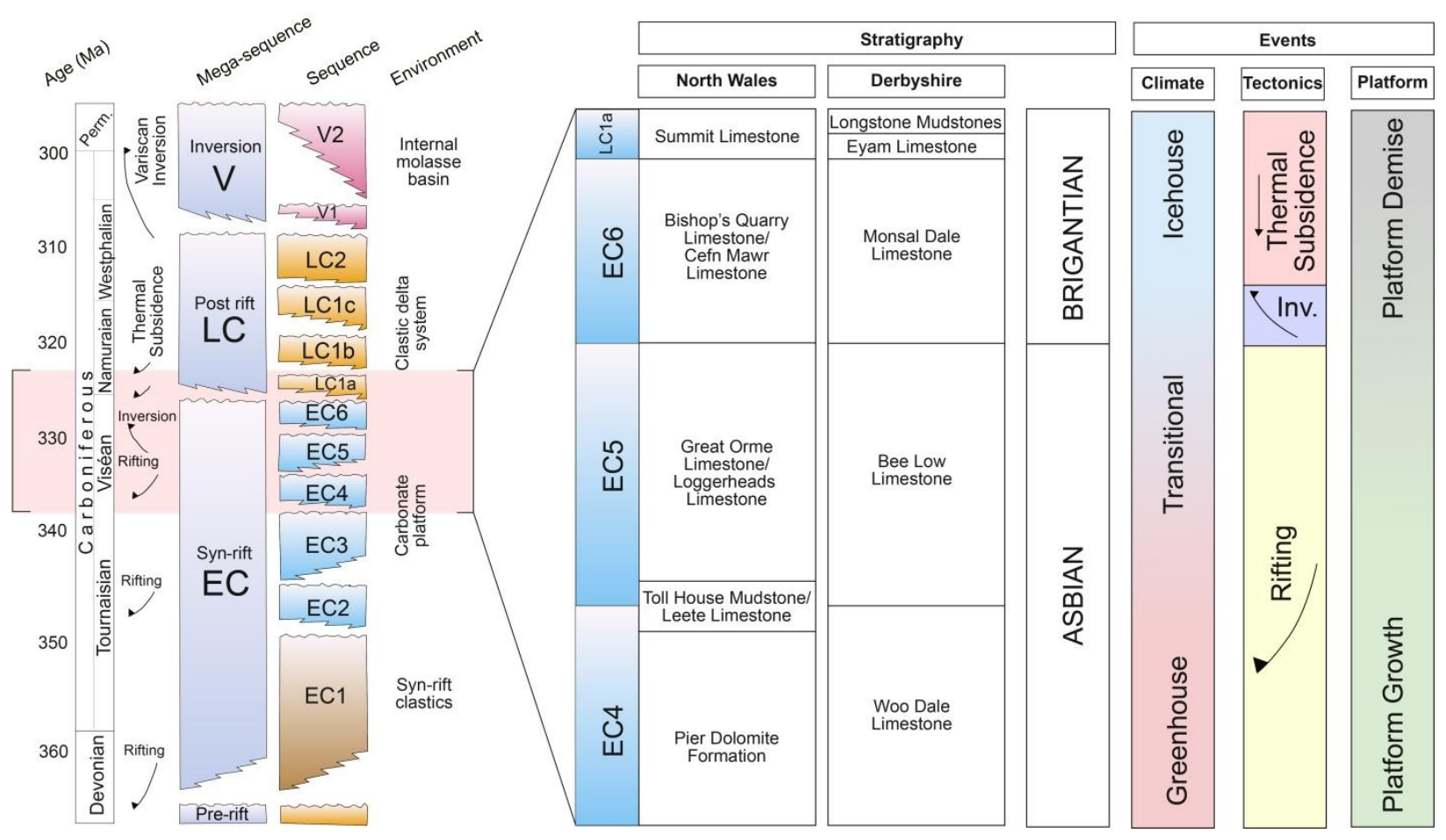

Figure 2 


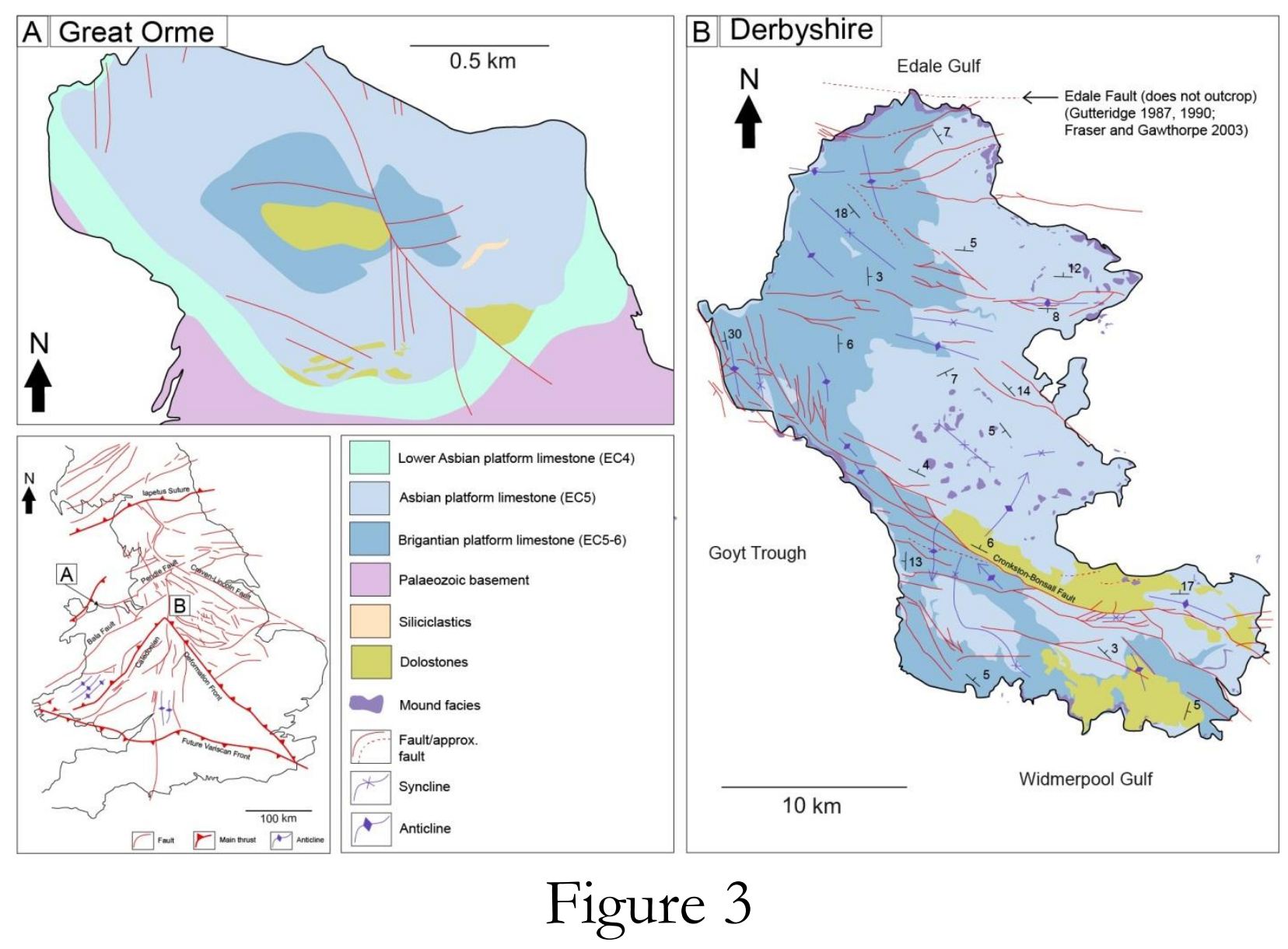



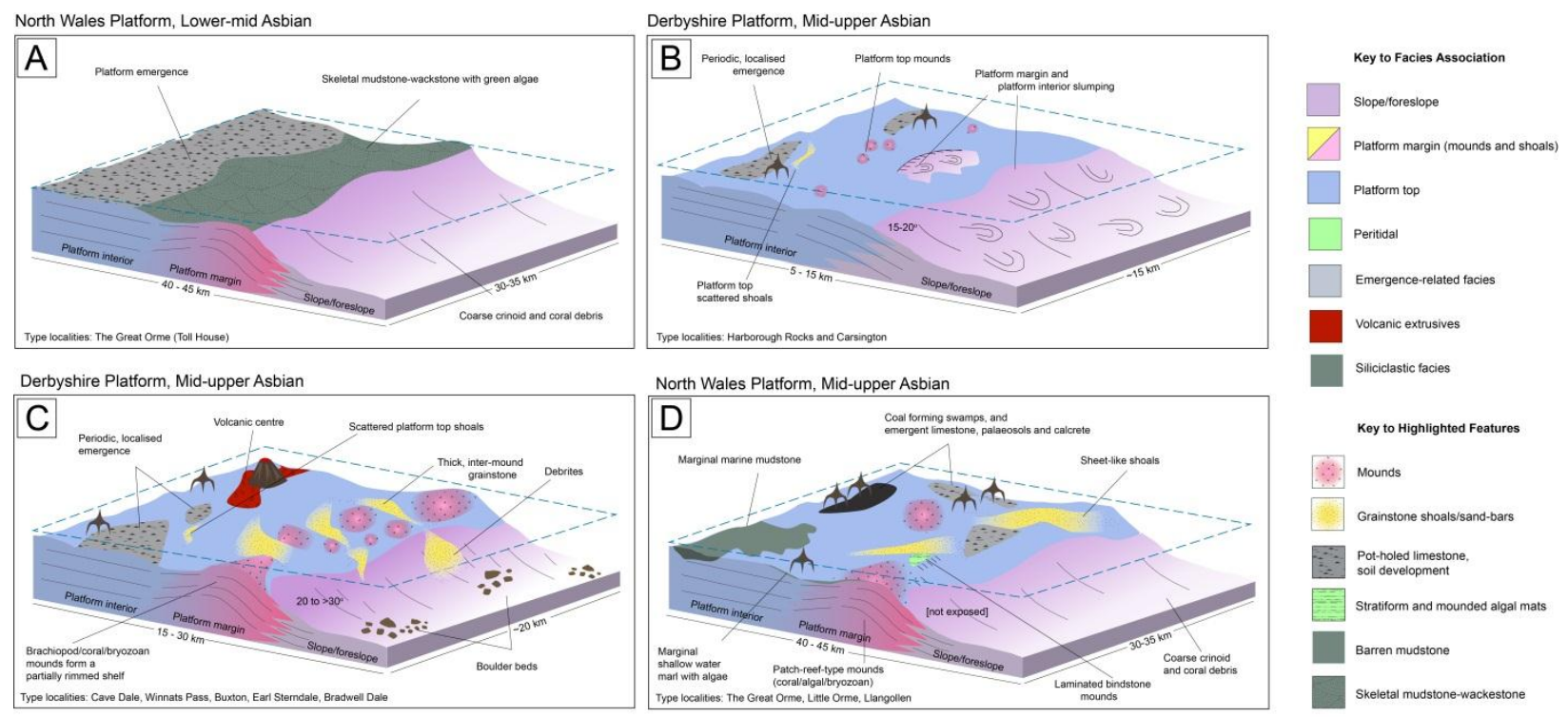

Figure 4 

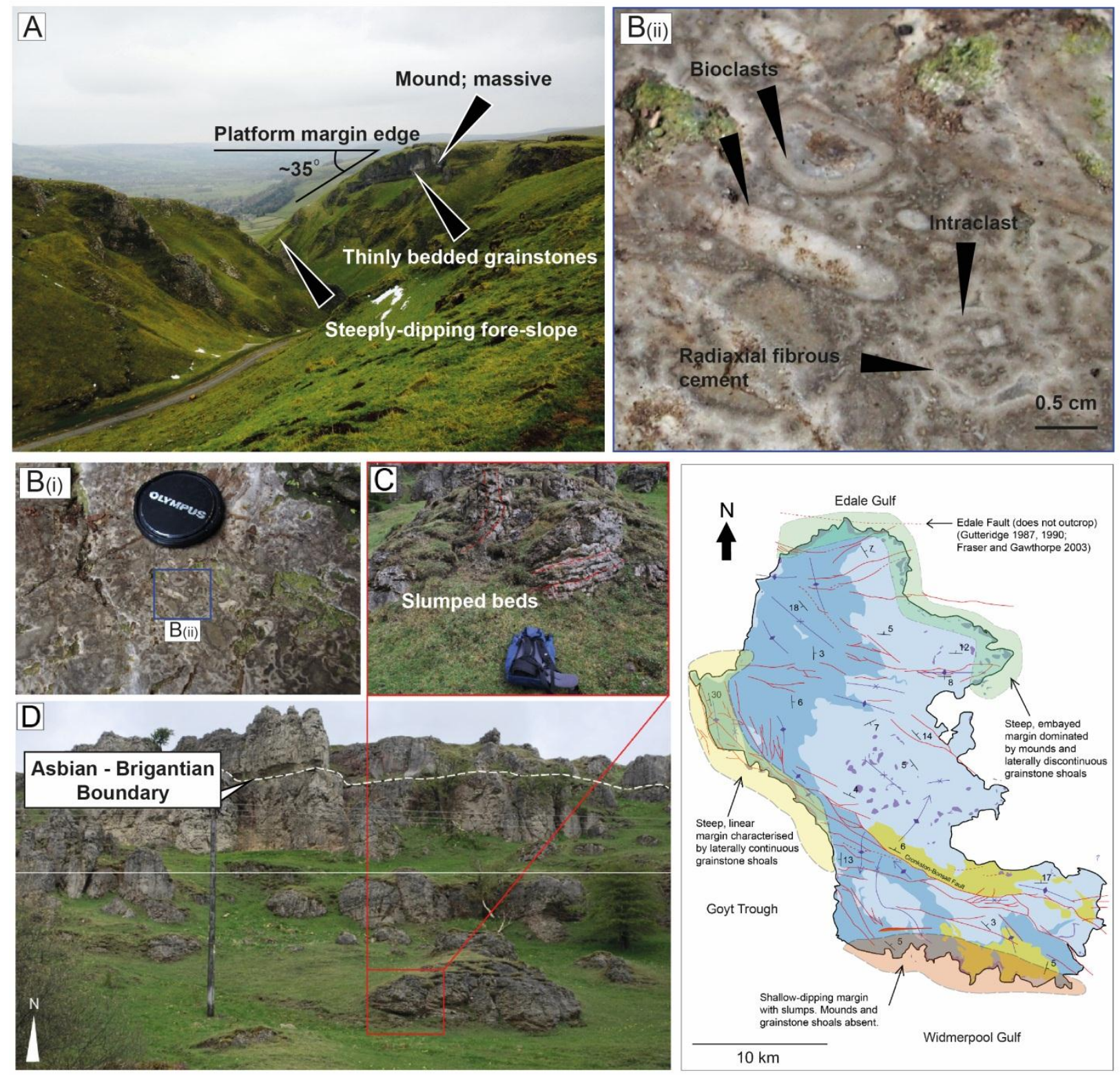

Figure 5 

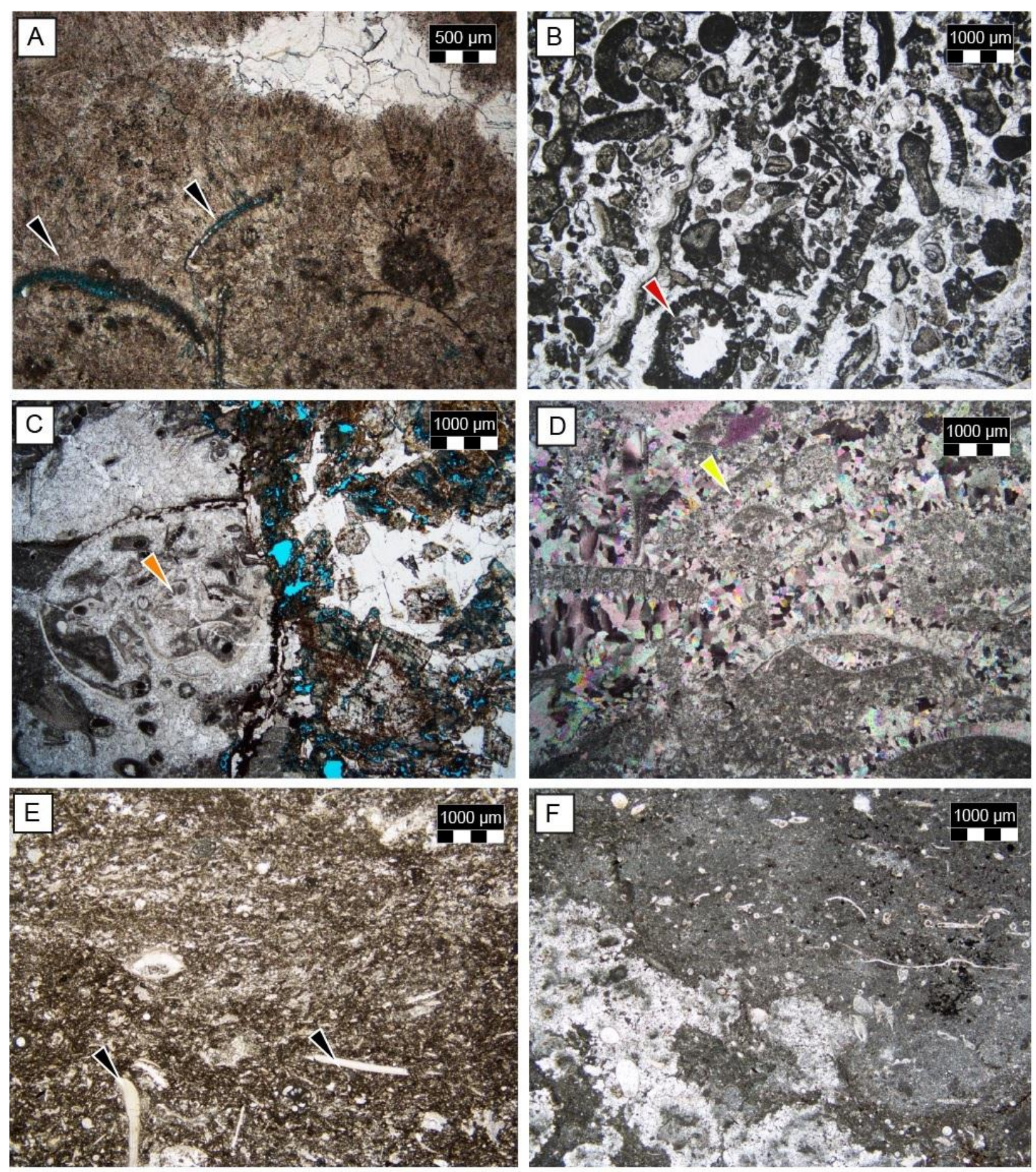

1 Brachiopod

Koninckopora inflata

Fenestrate bryozoa

Dasycladacean algae

\section{Figure 6}




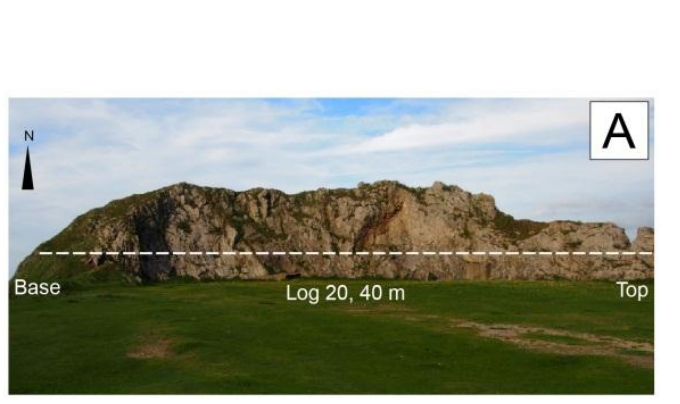

A $\quad \log 20$

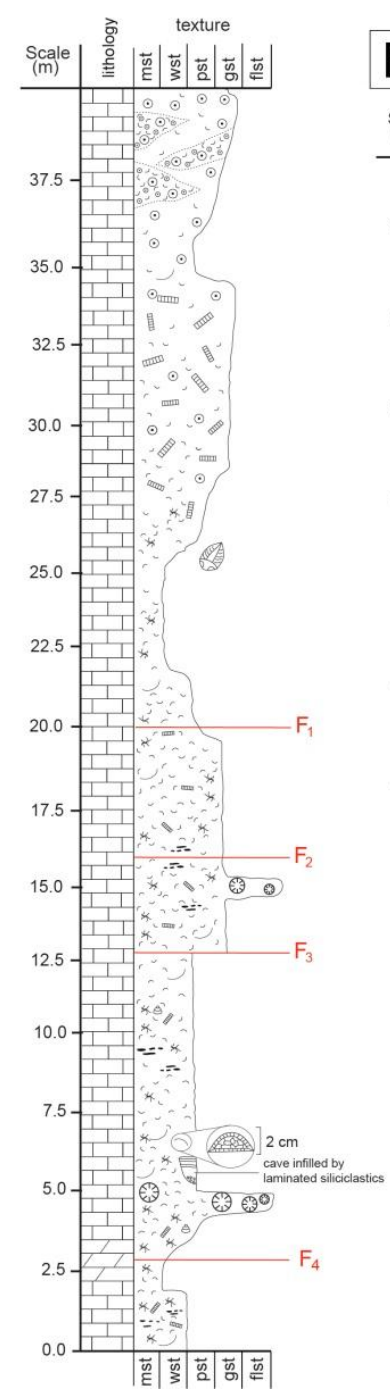

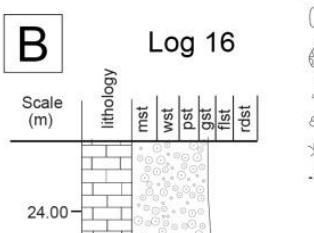
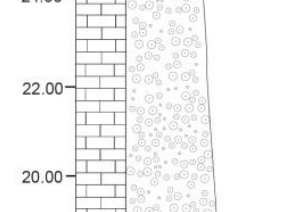

C $\quad \log 15$

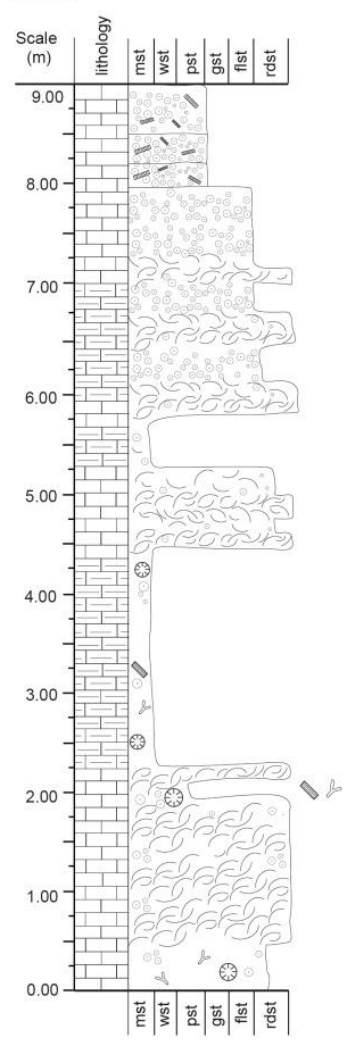

Figure 7 

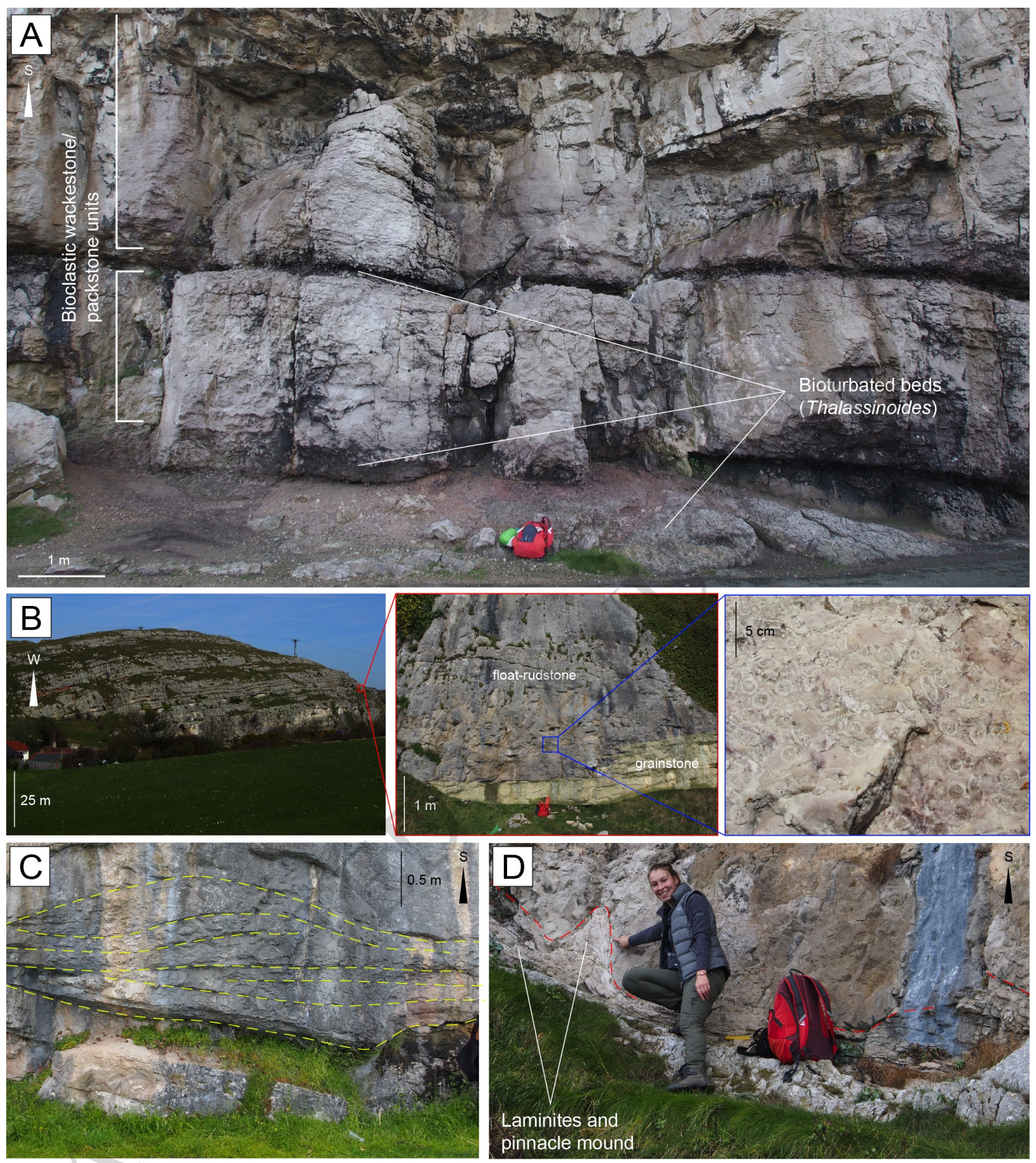

\section{Figure 8}



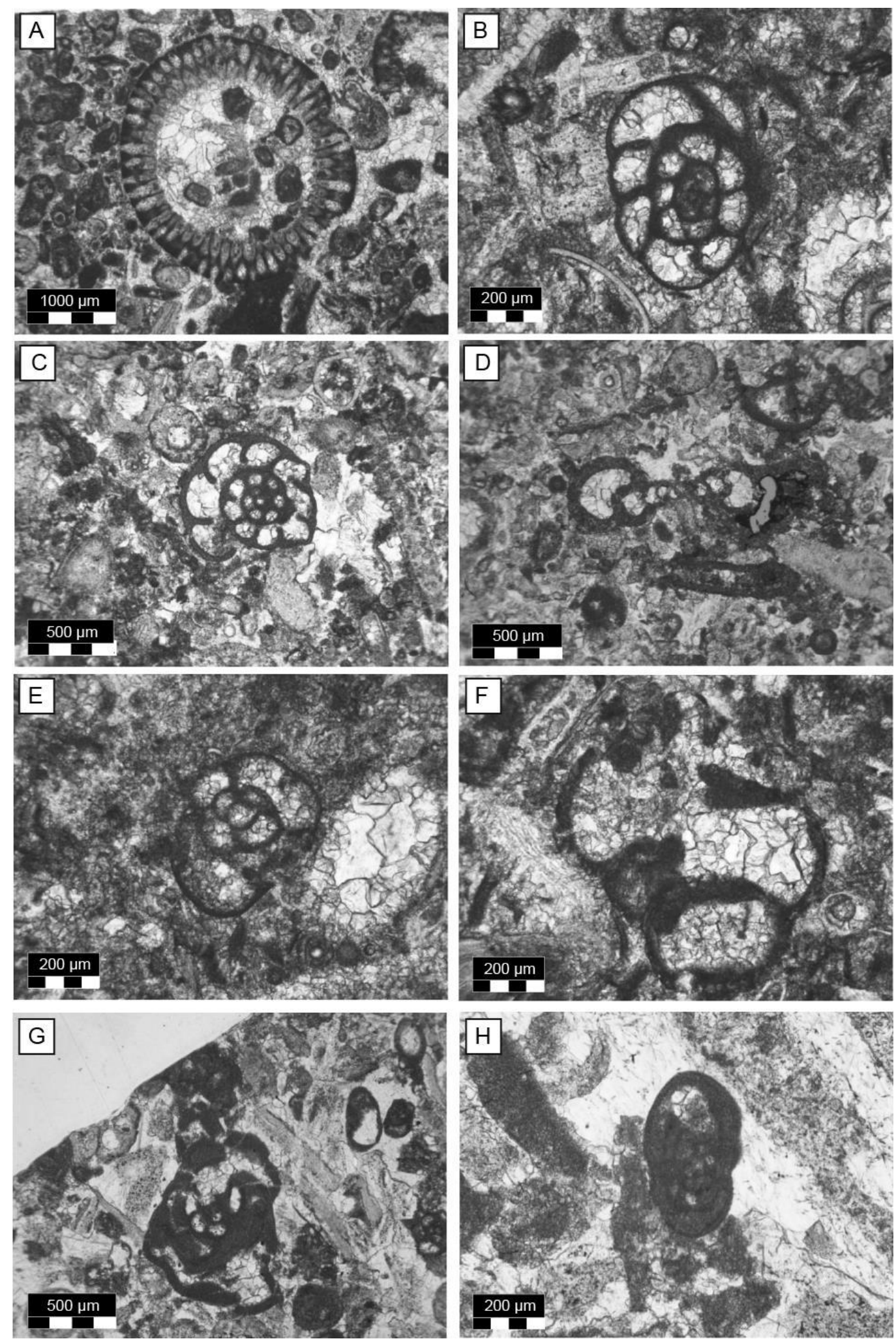

\section{Figure 9}



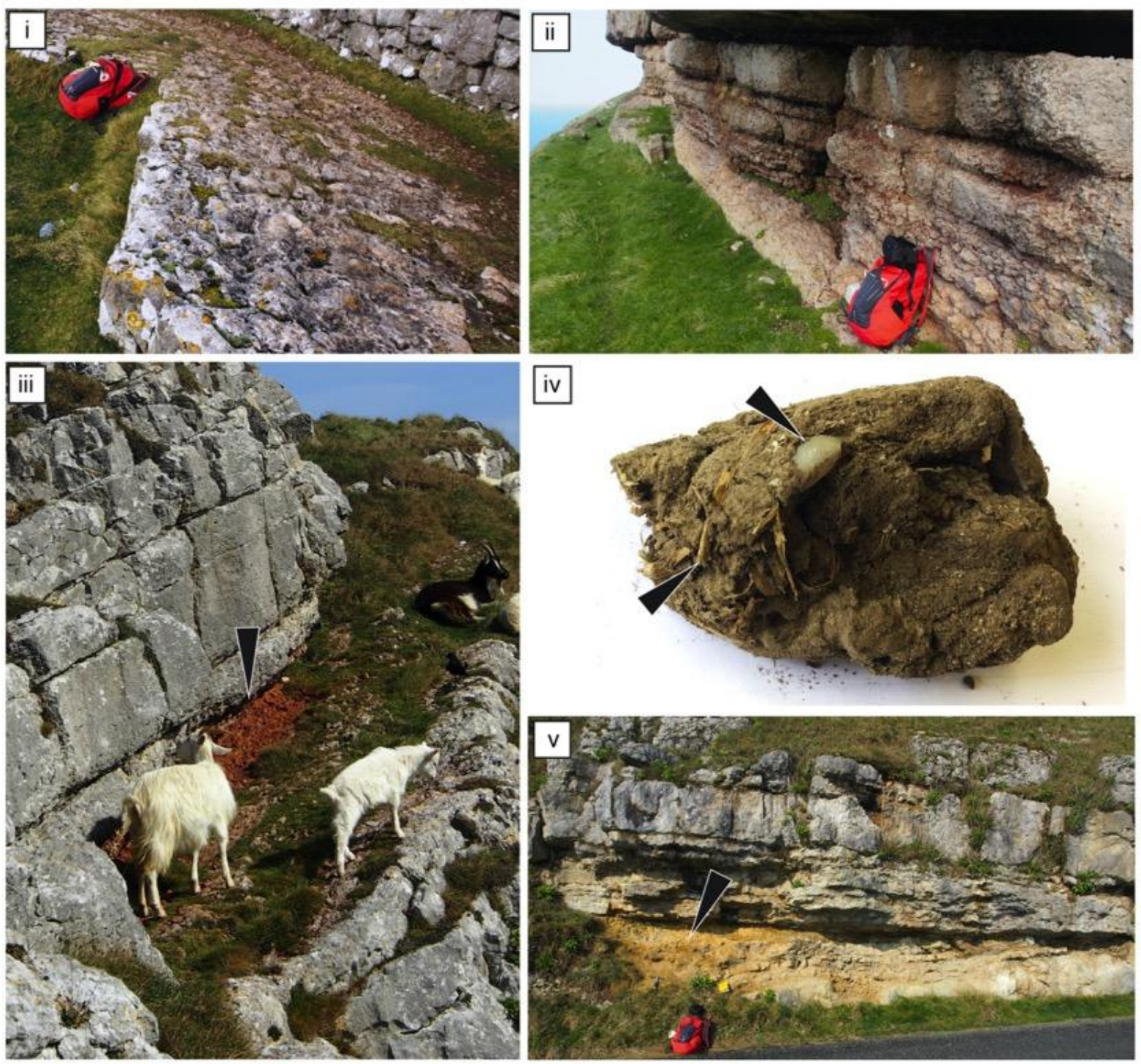

Figure 10a 

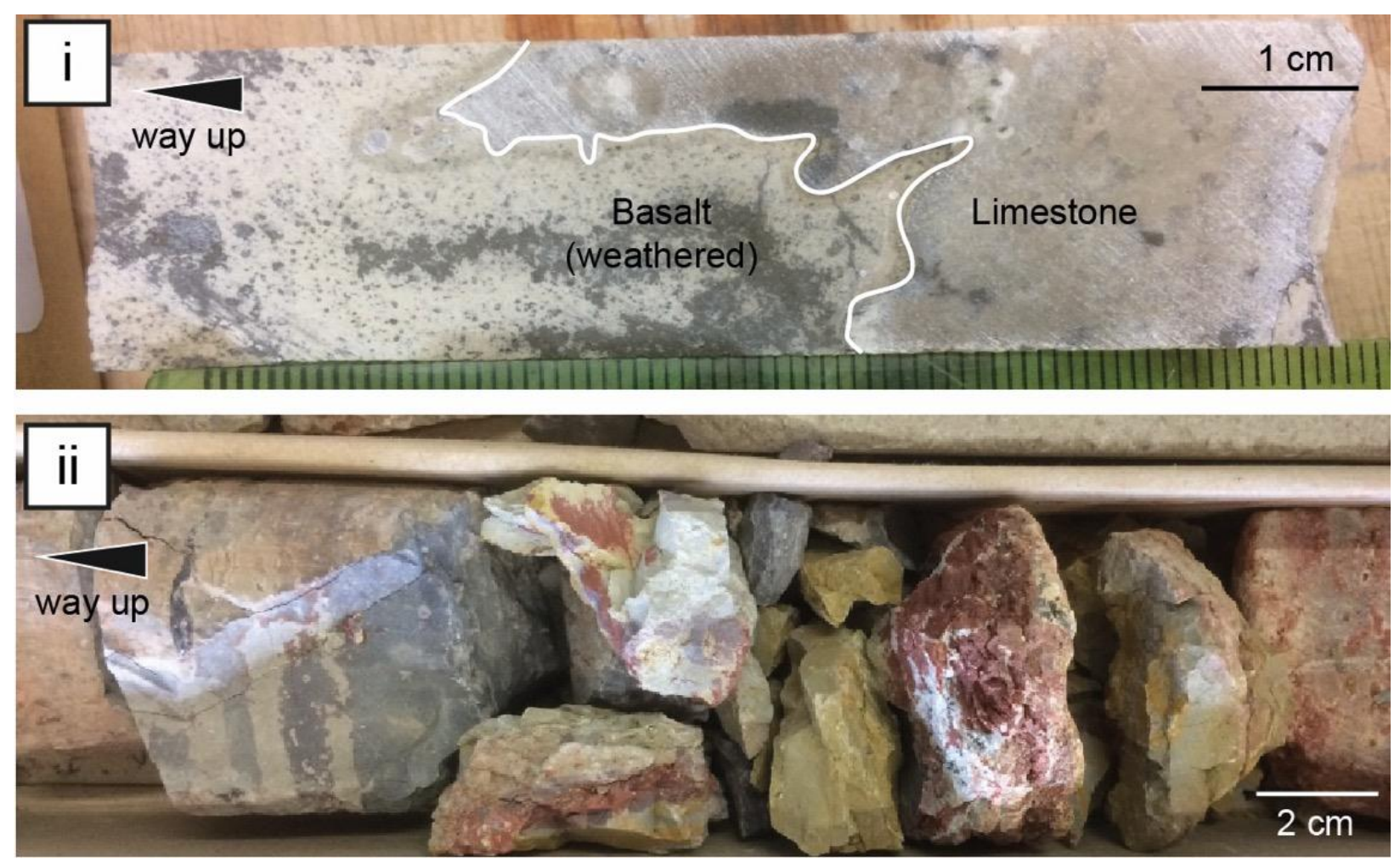

Figure 10b 

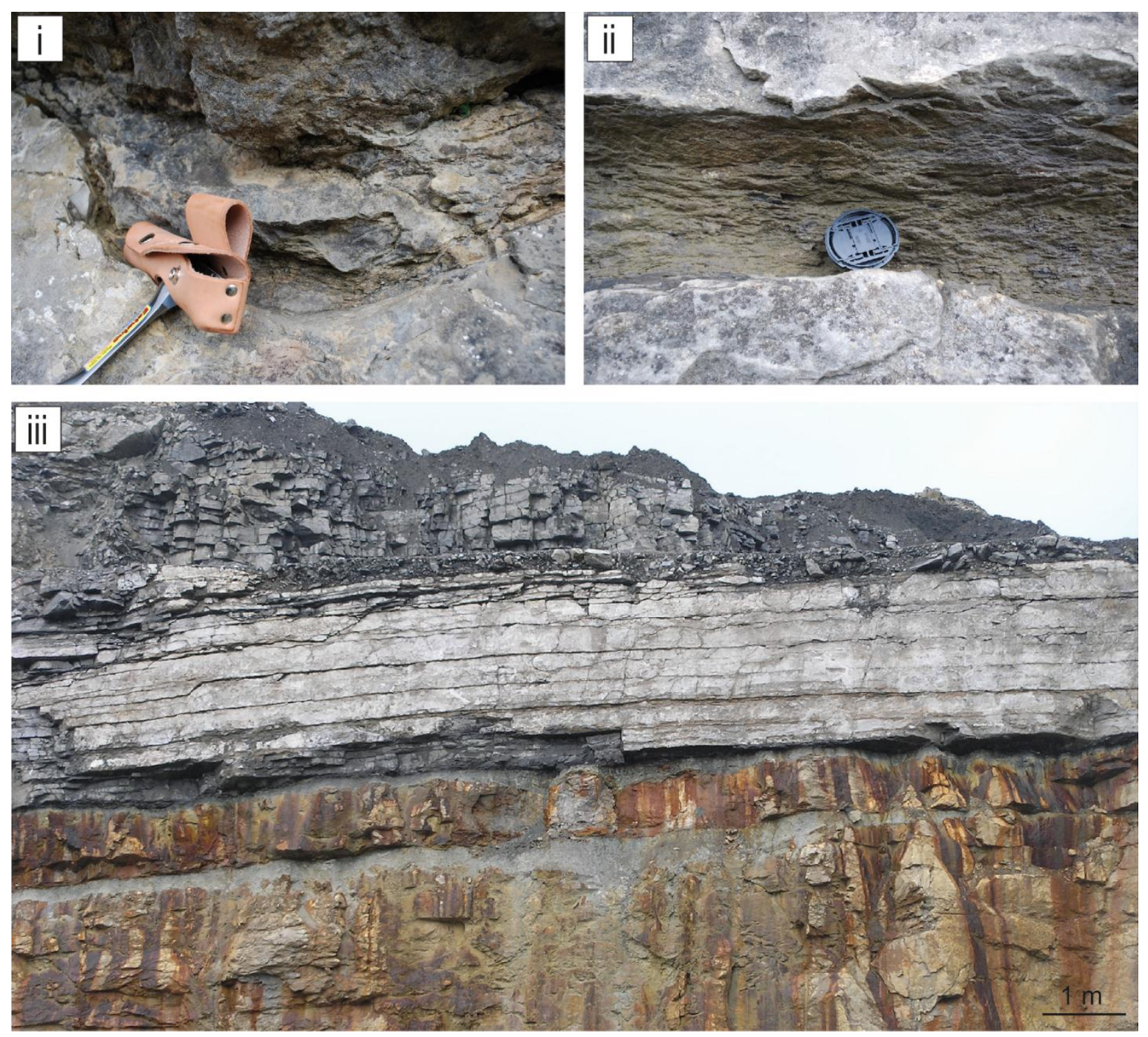

\section{Figure 10c}



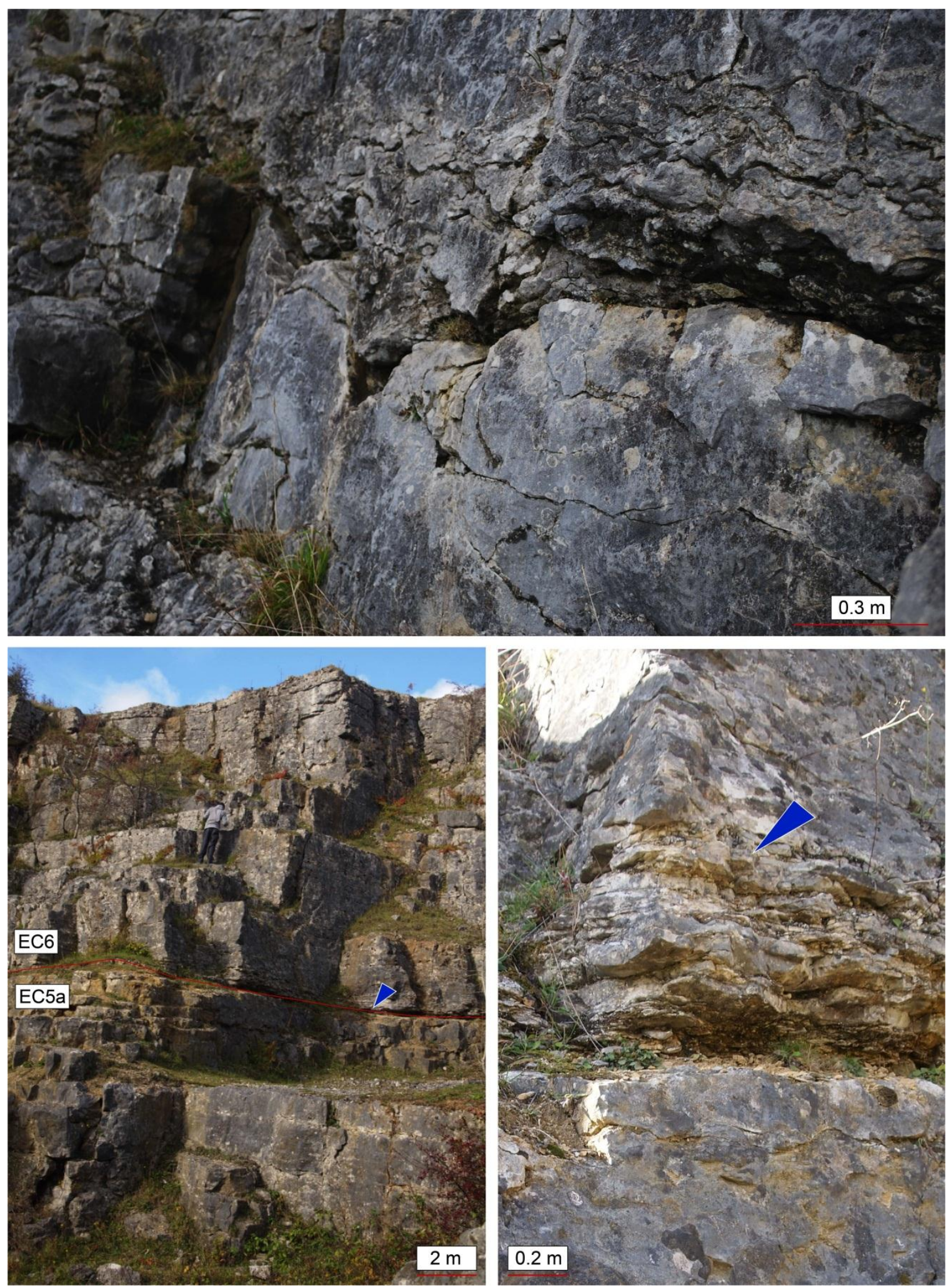

Figure 11 


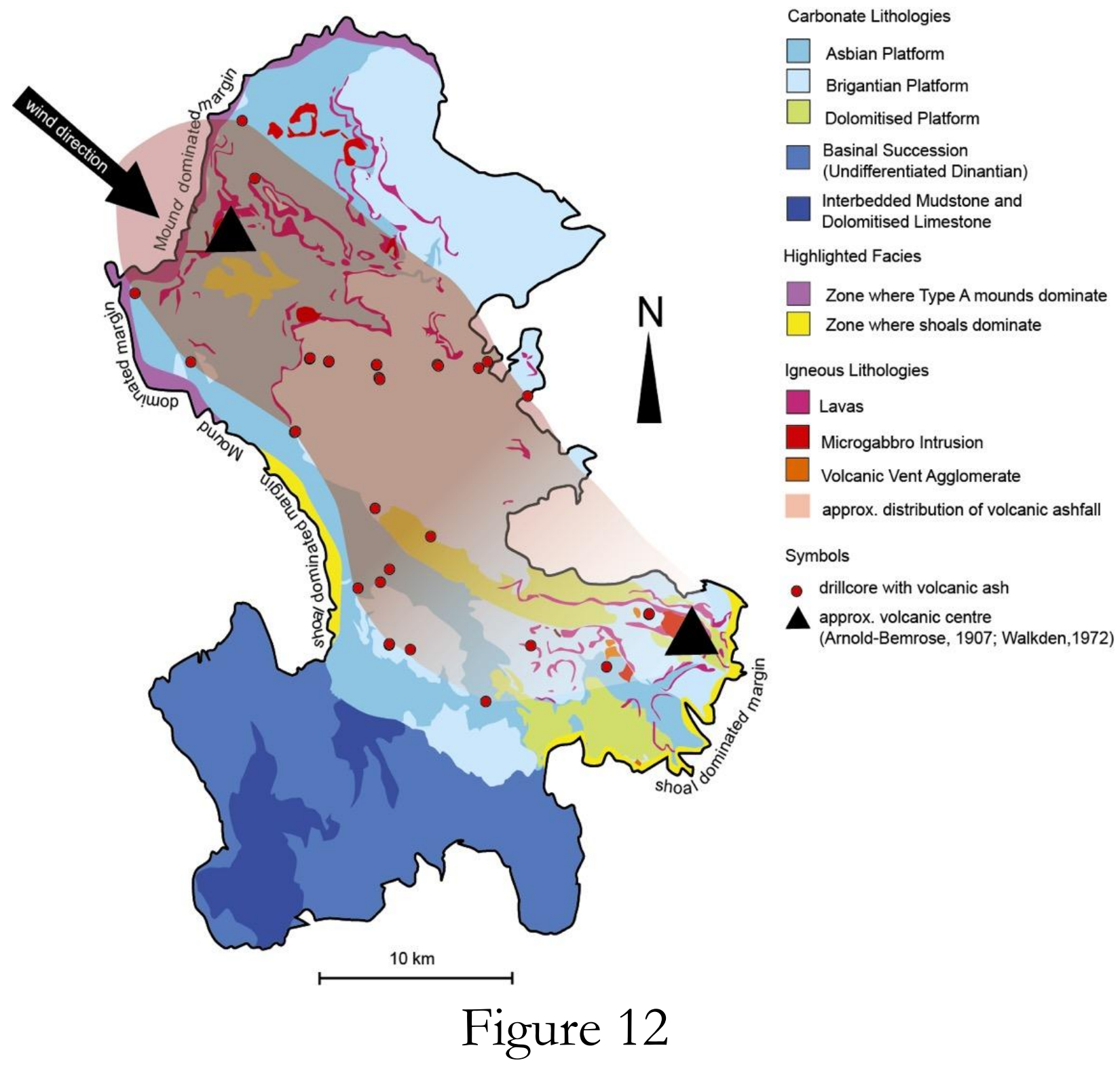




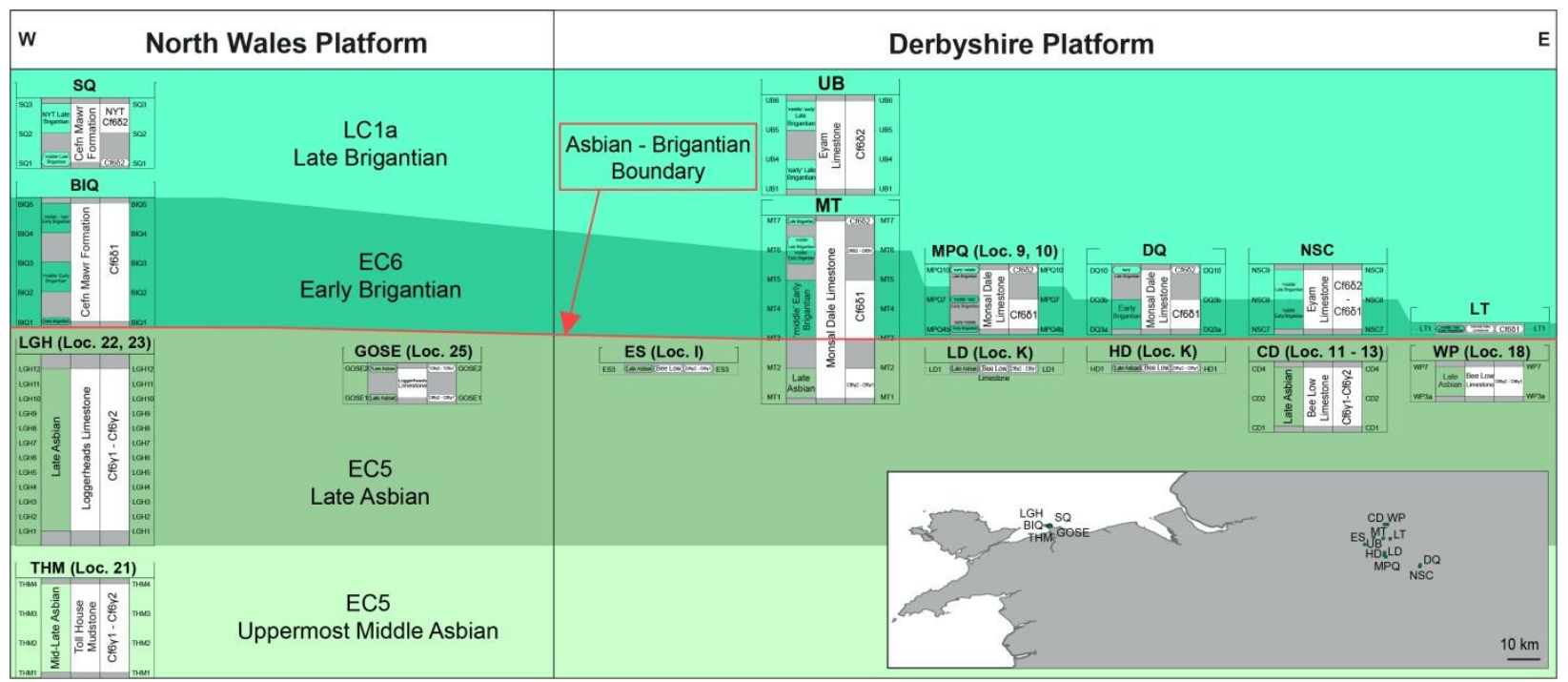

Figure 13 
Downloaded from http://jgs.lyellcollection.org/ at University of Manchester, The John Rylands University Library on February 28, 2021

Tables

Locality number

DP/NWP Source Length (m) Easting Northing

\begin{tabular}{|c|c|c|c|c|c|c|}
\hline 1 & Cardlemere Lane & $\mathrm{DP}$ & $\mathrm{C}$ & 35.7 & 417627 & 358349 \\
\hline 2 & Gratton Moor & $\mathrm{DP}$ & $\mathrm{C}$ & 41.9 & 420350 & 360340 \\
\hline 3 & Lees Bottom & $\mathrm{DP}$ & $\mathrm{C}$ & 40.2 & 417050 & 370500 \\
\hline 4 & Bee Low Quarry & $\mathrm{DP}$ & $\mathrm{C}$ & 100 & 408540 & 379040 \\
\hline 5 & Biggin & $\mathrm{DP}$ & $\mathrm{C}$ & 100 & 415250 & 358200 \\
\hline 6 & Four Lane Ends & $\mathrm{DP}$ & $\mathrm{C}$ & 42 & 427295 & 354327 \\
\hline 7 & Hurdlow Town & $\mathrm{DP}$ & $\mathrm{C}$ & 120 & 411347 & 366736 \\
\hline 8 & Longcliffe & $\mathrm{DP}$ & $\mathrm{C}$ & 21 & 422090 & 356440 \\
\hline 9 & Middle Peak Quarry (1) & $\mathrm{DP}$ & $\mathrm{O}$ & 8.55 & 427882 & 355009 \\
\hline 10 & Middle Peak Quarry (2) & $\mathrm{DP}$ & $\mathrm{O}$ & 4.26 & 428193 & 354894 \\
\hline 11 & Cave Dale (1) & $\mathrm{DP}$ & $\mathrm{O}$ & 8 & 415059 & 382607 \\
\hline 12 & Cave Dale (2) & $\mathrm{DP}$ & $\mathrm{O}$ & 7 & 415016 & 382609 \\
\hline 13 & Cave Dale (3) & $\mathrm{DP}$ & $\mathrm{O}$ & 12 & 415016 & 382570 \\
\hline 14 & Pin Dale Quarry (1) & $\mathrm{DP}$ & $\mathrm{O}$ & 6.5 & 415814 & 382279 \\
\hline 15 & Pin Dale Quarry (2) & $\mathrm{DP}$ & $\mathrm{O}$ & 9 & 416083 & 382332 \\
\hline 16 & Pin Dale Quarry (3) & $\mathrm{DP}$ & $\mathrm{O}$ & 26 & 416083 & 382332 \\
\hline 17 & Carsington & $\mathrm{DP}$ & $\mathrm{O}$ & 4 & 427941 & 353868 \\
\hline 18 & Winnats Pass (1) & $\mathrm{DP}$ & $\mathrm{O}$ & 15.8 & 413792 & 382719 \\
\hline 19 & $\begin{array}{l}\text { Great Orme South West } \\
\text { (1) }\end{array}$ & NWP & $\mathrm{O}$ & 43.1 & 276633 & 382430 \\
\hline 20 & Little Orme Mound & NWP & $\mathrm{O}$ & 40 & 281885 & 382664 \\
\hline 21 & Marine Drive (1) & NWP & $\mathrm{O}$ & 3.6 & 278132 & 383263 \\
\hline 22 & Marine Drive (2) & NWP & $\mathrm{O}$ & 9.5 & 275295 & 383827 \\
\hline 23 & Marine Drive (3) & NWP & $\mathrm{O}$ & 10.5 & 278120 & 383763 \\
\hline 24 & $\begin{array}{l}\text { Great Orme South West } \\
(2)\end{array}$ & NWP & $\mathrm{O}$ & 67 & 276646 & 382813 \\
\hline 25 & Great Orme South East (1) & NWP & $\mathrm{O}$ & 52 & 277621 & 382903 \\
\hline 26 & BLBP33F147 & $\mathrm{DP}$ & $\mathrm{L}$ & 243 & 418857 & 369666 \\
\hline 27 & BLBP40F17A & $\mathrm{DP}$ & $\mathrm{L}$ & 243.4 & 423334 & 361206 \\
\hline 28 & BLBP40F17B & $\mathrm{DP}$ & $\mathrm{L}$ & 235.6 & 423769 & 361449 \\
\hline 29 & BLBP41F18B & $\mathrm{DP}$ & $\mathrm{L}$ & 197 & 419075 & 361004 \\
\hline 30 & CELFMB9 & $\mathrm{DP}$ & $\mathrm{L}$ & 67.5 & 414693 & 381719 \\
\hline 31 & CELFMB13 & $\mathrm{DP}$ & $\mathrm{L}$ & 54.9 & 414681 & 381810 \\
\hline 32 & CELFP722 & $\mathrm{DP}$ & $\mathrm{L}$ & 19.5 & 408573 & 378387 \\
\hline 33 & CELFP723 & $\mathrm{DP}$ & $\mathrm{L}$ & 29.9 & 408208 & 377473 \\
\hline 34 & CELFP726 & $\mathrm{DP}$ & $\mathrm{L}$ & 84.5 & 418944 & 376568 \\
\hline 35 & CELFP727 & $\mathrm{DP}$ & $\mathrm{L}$ & 84.5 & 417279 & 375122 \\
\hline 36 & CELFMB14 & $\mathrm{DP}$ & $\mathrm{L}$ & 64.8 & 414604 & 381653 \\
\hline 37 & CELFMB15 & $\mathrm{DP}$ & $\mathrm{L}$ & 68.4 & 414511 & 381740 \\
\hline 38 & CELFMB16 & $\mathrm{DP}$ & $\mathrm{L}$ & 40.5 & 414617 & 381770 \\
\hline 39 & CELFAF3 & $\mathrm{DP}$ & $\mathrm{L}$ & 81 & 414851 & 381982 \\
\hline
\end{tabular}


Downloaded from http://jgs.lyellcollection.org/ at University of Manchester, The John Rylands University Library on February 28, 2021

\begin{tabular}{lllllll}
40 & CELFAF4 & DP & L & 84.6 & 415112 & 382094 \\
\hline 41 & CELFAF1 & DP & L & 72.9 & 414963 & 382249 \\
\hline 42 & CELFAF2 & DP & L & 83.7 & 415160 & 382272 \\
\hline 43 & CELFAF5 & DP & L & 111.6 & 415587 & 382119 \\
\hline 44 & CELFP2 & DP & L & 36 & 415927 & 382199 \\
\hline 45 & CELFP721 & DP & L & 24.2 & 414218 & 380272 \\
\hline 46 & CELFP725 & DP & L & 43.4 & 415126 & 382533
\end{tabular}

Table 1a. Log names, platform which log was undertaken (DP = Derbyshire Platform, NWP = North Wales Platform), data source ( $\mathrm{O}=$ outcrop, $\mathrm{C}=$ core, $\mathrm{L}=$ literature). Note logs starting BLBP: Aitkenhead et al (1985), P = page number; $F=$ figure number. Logs starting CELF: Stevenson and Gaunt (1971), P = page number; F = figure number; $\mathrm{MB}=$ name used in literature.

\begin{tabular}{llll} 
& & $\begin{array}{l}\text { Easting (UK National } \\
\text { Grid) }\end{array}$ & $\begin{array}{l}\text { Northing (UK National } \\
\text { Grid) }\end{array}$ \\
\hline A & Castleton & 415086 & 382935 \\
\hline B & Buxton & 405757 & 373139 \\
\hline C & Matlock & 429894 & 360294 \\
\hline D & Great Orme & 276750 & 383335 \\
\hline E & Little Orme & 281298 & 382384 \\
\hline F & Penmon Point & 264076 & 381251 \\
\hline G & Llangollen & 321495 & 342006 \\
\hline H & Cefn Mawr & 310823 & 293820 \\
\hline I & Earl Sterndale & 408014 & 366937 \\
\hline J & Monsal Trail & 416761 & 372610 \\
\hline K & Hand Dale/Long Dale (near & 413770 & 361204
\end{tabular}

Table 1b: Additional Localities, not logged but mapped and mentioned in text and shown in Figure 1. Grid references are the central point to the general area which may be $<5 \mathrm{~km}^{2}$. 


\begin{tabular}{|c|c|c|c|c|c|c|c|c|c|}
\hline $\begin{array}{l}\text { Depositional } \\
\text { Environment }\end{array}$ & Facies & Distribution & Texture and geometry & Average grain volume & $\begin{array}{l}\text { Average matrix and } \\
\text { cement volume }\end{array}$ & $\begin{array}{l}\begin{array}{l}\text { Sedimentary } \\
\text { structures }\end{array} \\
\end{array}$ & Biogenic structures & Diagenetic features & Interpretation \\
\hline $\begin{array}{l}\text { Slope / } \\
\text { foreslope }\end{array}$ & $\begin{array}{l}\text { Limestone boulders, } \\
\text { several metres in } \\
\text { diameter, forming a } \\
\text { matrix-supported } \\
\text { conglomerate } \\
\text { Slumped } \\
\text { wack/packstone and } \\
\text { floatstone }\end{array}$ & $\begin{array}{l}\text { Matrix supported } \\
\text { conglomerate and } \\
\text { boulders only occur on } \\
\text { northern and western } \\
\text { margin of Derbyshire } \\
\text { Platform } \\
\text { Slumped } \\
\text { wack/packstone occurs } \\
\text { on southern margin of } \\
\text { Derbyshire Platform }\end{array}$ & $\begin{array}{l}\text { Matrix-supported } \\
\text { conglomerate has } \\
\text { pooly sorted } \\
\text { wack/packstone clasts } \\
\text { (0.5-100m diameter) } \\
\text { and fragmented skeletal } \\
\text { debris }\end{array}$ & 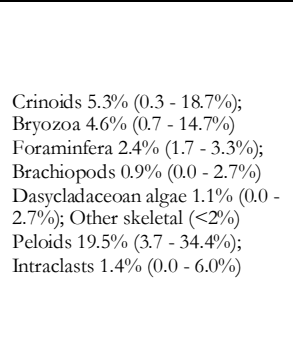 & $\begin{array}{l}\text { Micrite } 15 \%(0 \text { - } \\
41 \% \text { ) } \\
\text { Radiaxial fibrous } \\
\text { calcite } 48 \%(37 \text { - } \\
688 \%) \\
\text { Dolomite }<1 \% \text {; } \\
\text { Bitumen }<1 \%\end{array}$ & $\begin{array}{l}\text { Conglomerate dips } \\
\text { at }>30^{\circ} \text { north towards } \\
\text { basin, with poorly } \\
\text { defined cross beds } \\
\text { Slumped beds dip at } \\
\sim 20^{\circ} \text { o outh, towards } \\
\text { basin }\end{array}$ & None & $\begin{array}{l}\text { Geopetal cement in } \\
\text { brachopod moulds } \\
\text { within conglomerate } \\
\text { dip at } \sim 30^{\circ} \\
\text { Conglomeratic clasts } \\
\text { coated by radiaxial } \\
\text { fibrous calcite } \\
\text { Slumped } \\
\text { wack/packstone } \\
\text { beds are } \\
\text { differentially } \\
\text { dolomitized }\end{array}$ & $\begin{array}{l}\text { Coarse grain size (pebbles and boulders) indicate } \\
\text { mass transport by gravity } \\
\text { Localisation of facies on platform margins and } \\
\text { palaeo-dips are consistent with slope } \\
\text { sedimentation, with periodic mobilisation of } \\
\text { sediment, e.g. due to faulting/mass wasting } \\
\text { Radiaxial fibrous calcite cement formed on } \\
\text { windward margin by seawater circulation, binding } \\
\text { clasts and stabilising a high slope angle } \\
\text { On the leeward margin, lower slope angles } \\
\text { developed, with periodic slumping induced by } \\
\text { tectonic activity }\end{array}$ \\
\hline $\begin{array}{l}\text { Platform } \\
\text { margin }\end{array}$ & $\begin{array}{l}\text { Mounded, skeletal } \\
\text { wackestone } \\
\text { Skeletal grainstone } \\
\text { Laminated and } \\
\text { stratiform bindstone } \\
\text { Siphonodendron } \\
\text { rudstone - framestone }\end{array}$ & $\begin{array}{l}\text { Mounded facies are } \\
\text { located on the northern } \\
\text { and western margins of } \\
\text { the North Wales and } \\
\text { Derbyshire Platforms } \\
\text { Skeletal } \\
\text { wack/packstones occur } \\
\text { between mounds } \\
\text { Skeletal grainstones } \\
\text { downlap onto } \\
\text { carbonate mounds and } \\
\text { form isolated sheets }\end{array}$ & $\begin{array}{l}\text { Dome-shaped mounds } \\
\text { up to } 40 \mathrm{~m} \text { wide and } \\
9 \mathrm{~m} \text { high, with core of } \\
\text { crinoids, brachiopds } \\
\text { and bryozoa with } \\
\text { peloidal cement and } \\
\text { crinoidal pack- and } \\
\text { grainstone flanks } \\
\text { Skeletal wack- } \\
\text { packstone within } \\
\text { intermound areas } \\
\text { comprising fragmented } \\
\text { bryozoa, brachopods, } \\
\text { corals, foraminifera and } \\
\text { micrite } \\
\text { Grainstones dominated } \\
\text { by crinoids with } \\
\text { fragmented bryozoa, } \\
\text { benthicformainifera, } \\
\text { Konickopora }\end{array}$ & 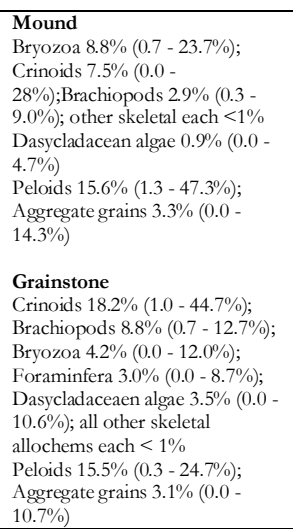 & $\begin{array}{l}\text { Mound } \\
\text { Micrite } 19.7 \%(0.0- \\
41.3 \%) \\
\text { Sparite cement } \\
38.6 \%(23.3-53.5 \%) \\
\text { Grainstone } \\
\text { Micrite } 0.4 \%(0.0- \\
2.3 \%) \\
\text { Sparite cement } \\
34.4 \%(16.3-64.0 \%) \\
\text { Bitumen } 0.1 \%(0.0- \\
0.3 \%)\end{array}$ & $\begin{array}{l}\text { Sheet-like } \\
\text { grainstones are } \\
\text { cross-bedded, thickly } \\
\text { bedded }(<2 \mathrm{~m}) \text {, up } \\
\text { to } 5 \mathrm{~m} \text { thick and } \\
\text { pinch out laterally } \\
\text { over }<100 \text { metres } \\
\text { Intermound } \\
\text { grainstones downlap } \\
\text { onto mounds and } \\
\text { are }<10 \mathrm{~m} \text { wide and } \\
<10 \mathrm{~m} \text { thick }\end{array}$ & None & $\begin{array}{l}\text { Abundant peloidal } \\
\text { and radiaxial fibrous } \\
\text { calcite cement } \\
\text { throughout mounds } \\
\text { Skeletal grainstones } \\
\text { cemented by clear, } \\
\text { blocky and sparry } \\
\text { calcite }\end{array}$ & $\begin{array}{l}\text { Platform margin mounds formed by trapping and } \\
\text { binding of skeletal grains by lime mud, potentially } \\
\text { facilitated by microbial binding, although evidence } \\
\text { for this is cryptic } \\
\text { Intermound areas accumulated fine-grained, } \\
\text { fragmented skeletal debris and lime mud } \\
\text { Skeletal grainstones formed sheet-like bodies in } \\
\text { high energy areas of the platform margin and } \\
\text { onlapped mounds }\end{array}$ \\
\hline Platform top & $\begin{array}{l}\begin{array}{l}\text { Mounded skeletal } \\
\text { mudstone- } \\
\text { wackestone }\end{array} \\
\text { Mottled } \\
\text { mud/wackestone } \\
\text { Skeletal } \\
\text { wack/packstone } \\
\text { Skeletal grainstone }\end{array}$ & $\begin{array}{l}\text { Mounds are localised } \\
\text { on the Derbyshire } \\
\text { Platrorm, on the } \\
\text { platorm top, with low } \\
\text { height - to - width ratio } \\
\text { (20m wide and } 15 \mathrm{~m} \\
\text { high) } \\
\text { Mounds often occur on } \\
\text { top of skeletal } \\
\text { grainstones } \\
\text { Skeletal grainstones are } \\
<0.3 \mathrm{~m} \text { thick and } 3 \text { - } 10 \\
\mathrm{~m} \text { wide }\end{array}$ & $\begin{array}{l}\text { Mounds comprise } \\
\text { Sibponodendron corals, } \\
\text { brachiopds, bryozoa, } \\
\text { demosponges and } \\
\text { gastropods } \\
\text { Skeletal grainstones } \\
\text { comprise Dajocladacean } \\
\text { algae, brachiopods, } \\
\text { benthic foraminfera } \\
\text { and peloids } \\
\text { Skeletal wackestone } \\
\text { comprises bethic } \\
\text { foraminfera, } \\
\text { brachiopods, crinoids, } \\
\text { bryozoa and serpulids. }\end{array}$ & 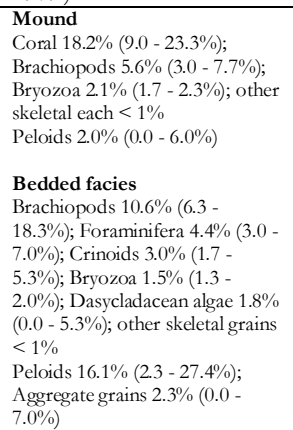 & $\begin{array}{l}\text { Mound } \\
\text { Micrite } 44.5 \%(40.7- \\
\text { 48.0\%) } \\
\text { Sparite cement } \\
24.3 \% \%(21.3-26.3 \%) \\
\text { Dolomite }<1 \% \\
\text { Bedded facies } \\
\text { Micrite } 40.3 \%(38.7- \\
41.3 \%) \\
\text { Sparite cement } 8.0 \% \\
(1.7-11.7 \%)\end{array}$ & $\begin{array}{l}\text { With the exception } \\
\text { of mounds, beds are } \\
\text { laterally continuous } \\
\text { and parallel bedded }\end{array}$ & $\begin{array}{l}\text { Skeletal wackestone } \\
\text { to mudstone has } \\
\text { dark, } \mathrm{cm} \text {-scale } \\
\text { mottling with diffuse } \\
\text { edges }\end{array}$ & $\begin{array}{l}\text { Compacted } \\
\text { (stylolitized) and } \\
\text { cemented by sparry } \\
\text { calcite }\end{array}$ & $\begin{array}{l}\text { Skeletal wack/packstone and grainstone are } \\
\text { typically flat bedded and laterally continuous on an } \\
\text { outcrop scale. They occur extensively across the } \\
\text { Derbyshire and North Wales Platform. } \\
\text { High diversity, high abundance skeletal assemblage } \\
\text { is consistent with moderate energy deposition in } \\
\text { the photic zone } \\
\text { Coral-dominated mounds are locally developed on } \\
\text { topographic highs and interpreted to have been } \\
\text { deposited under high energy conditions }\end{array}$ \\
\hline Peritidal & Algal laminite & $\begin{array}{l}\text { Very rare occurrence } \\
\text { on North Wales } \\
\text { Platform, beneath } \\
\text { emergent surfaces }\end{array}$ & $\begin{array}{l}\text { Crinkled, pinnacled } \\
\text { bindstone }\end{array}$ & Minor quartz and muscovite & - & & None & Minor halite & $\begin{array}{l}\text { Microbial bindstone deposited in intertidal setting. } \\
\text { Trapping of quartz and muscovite from terestrial } \\
\text { source. Halite consistent with evaporation }\end{array}$ \\
\hline
\end{tabular}




\begin{tabular}{|c|c|c|c|c|c|c|c|c|}
\hline $\begin{array}{l}\text { Emergence - } \\
\text { related facies }\end{array}$ & $\begin{array}{l}\text { A - Mammilated } \\
\text { surfaces } \\
\text { B - Nodular / } \\
\text { rubbled limestone } \\
\text { C - Unconsolidated } \\
\text { muds / clays } \\
\text { D - Coal }\end{array}$ & $\begin{array}{l}\text { Type A surfaces are } \\
\text { ubiquitous on both } \\
\text { plattorms. } \\
\text { Type B surfaces occur } \\
\text { on both platforms but } \\
\text { are thicker and more } \\
\text { extensive an North } \\
\text { Wales Platform } \\
\text { Type C \& D surfaces } \\
\text { are mostly restricted to } \\
\text { North Wales Platform. } \\
\text { Type D are only found } \\
\text { in the most ploximal } \\
\text { parts of the North } \\
\text { Wales Platform }\end{array}$ & $\begin{array}{l}\text { Type A surfaces have } \\
\text { wavelength of } 0.2 \text { to } 1 \\
\text { m, and downcut into } \\
\text { underlying beds. They } \\
\text { areo often coated by clay } \\
\text { rich in volcanic ash on } \\
\text { the Derbyshire } \\
\text { Platform } \\
\text { Type B surfaces are } \\
\text { <y.5 m thick and } \\
\text { comprise clast- } \\
\text { supported } \\
\text { conglomerates of } \\
\text { skeletal packstone } \\
\text { (nodules } 2 \text {-5cm } \\
\text { diameter) } \\
\text { Type C surfaces } \\
\text { comprise calcite, } \\
\text { kaalinite, muscovite } \\
\text { and quartz }\end{array}$ & - & - & \begin{tabular}{|l} 
Vertical and sub- \\
vertical, structureless \\
tubular structures with \\
a consistent diameter \\
underlie Type B \\
surfaces and have a \\
coarser grained \\
sediment fill than the \\
surrounding matrix are \\
interpreted as open \\
burrows formed in firm \\
sediment, prior to \\
emergence
\end{tabular} & $\begin{array}{l}\text { Type B surfaces, } \\
\text { nodules are cemented } \\
\text { by sparry calcite } \\
\text { Type C surfaces } \\
\text { include haematite }\end{array}$ & $\begin{array}{l}\text { Type A surfaces are interpreted to have formed by } \\
\text { erosion beneath soil cover } \\
\text { Type B surfaces are calcretes } \\
\text { Type C surfaces are paleosols } \\
\text { Type D surfaces are coals formed within swamps } \\
\text { close to the palaoe-shoreline }\end{array}$ \\
\hline $\begin{array}{l}\text { Igneous } \\
\text { rocks }\end{array}$ & $\begin{array}{l}\text { A - Amygdoloidal } \\
\text { basalt } \\
\text { B- Clay-rich layers }\end{array}$ & $\begin{array}{l}\text { This facies association } \\
\text { only occurs on the } \\
\text { Derbyshire Platform }\end{array}$ & $\begin{array}{l}\text { Type A - Amygdoloidal } \\
\text { basalt is interbedded } \\
\text { with limestone and } \\
\text { rarely forms localised, } \\
\text { columnar basalt } \\
\text { Type B - clays that lie } \\
\text { on top of mammilated } \\
\text { surfaces }\end{array}$ & . & & None & $\begin{array}{l}\text { Type A are massive, } \\
\text { dark green to greenish- } \\
\text { black, pyroxene-rich } \\
\text { with calcite cemented } \\
\text { vesicles } \\
\text { Type B comprises } \\
\text { multi-coloured, friable } \\
\text { clays }\end{array}$ & $\begin{array}{l}\text { Amydoloidal basalts interpreted as lava flows, with } \\
\text { columnar structures indicative of cooling to form } \\
\text { vertical joints } \\
\text { Clays have been analysed previously (Walkden, } \\
1972 \text { ) to be potassium bentonites, an alteration of } \\
\text { volcanic ash }\end{array}$ \\
\hline Siliciclastic & C - mudrock & $\begin{array}{l}\text { This facies association } \\
\text { only occurs on the } \\
\text { North Wales Platform }\end{array}$ & $\begin{array}{l}\text { Siliciclastic and forms } \\
\text { beds up to } \sim 1 \text { metre } \\
\text { thick beneath and } \\
\text { above emergent } \\
\text { surfaces }\end{array}$ & & $\begin{array}{l}\text { Planar laminated and } \\
\text { fissile }\end{array}$ & None & & $\begin{array}{l}\text { Mudrock is interpreted as marginal marine, since } \\
\text { they are only found in the most proximal settings, } \\
\text { in proximity to emergent surfaces }\end{array}$ \\
\hline
\end{tabular}

Table 2: Summary table of distribution, sedimentological characteristics and interpretation of facies associations and facies observed in the strata of the Derbyshire and North Wales Platforms, quantified using point counting of 300 points per thin section. 